\title{
Effect of Soil Classification on Seismic Behavior of SMFs considering Soil-Structure Interaction and Near-Field Earthquakes
}

\author{
Shahrokh Shahbazi, ${ }^{1}$ Iman Mansouri, ${ }^{2}$ Jong Wan Hu ${ }^{D},{ }^{3,4}$ and Armin Karami ${ }^{5}$ \\ ${ }^{1}$ TAAT Investment Group, Tehran 18717-13553, Iran \\ ${ }^{2}$ Department of Civil Engineering, Birjand University of Technology, Birjand 97175-569, Iran \\ ${ }^{3}$ Department of Civil and Environmental Engineering, Incheon National University, 12-1 Songdo-dong, Yeonsu-gu, \\ Incheon 22012, Republic of Korea \\ ${ }^{4}$ Incheon Disaster Prevention Research Center, Incheon National University, 12-1 Songdo-dong, Yeonsu-gu, \\ Incheon 22012, Republic of Korea \\ ${ }^{5}$ Department of Civil Engineering, Islamic Azad University, Central Tehran Branch, Tehran 13185-768, Iran
}

Correspondence should be addressed to Jong Wan Hu; jongp24@incheon.ac.kr

Received 10 June 2018; Revised 7 August 2018; Accepted 13 August 2018; Published 8 October 2018

Academic Editor: Tai Thai

Copyright (c) 2018 Shahrokh Shahbazi et al. This is an open access article distributed under the Creative Commons Attribution License, which permits unrestricted use, distribution, and reproduction in any medium, provided the original work is properly cited.

\begin{abstract}
Seismic response of a structure is affected by its dynamic properties and soil flexibility does not have an impact on it when the bottom soil of foundation is supposedly frigid, and the soil flexibility is also ignored. Hence, utilizing the results obtained through fixed-base buildings can lead to having an insecure design. Being close to the source of an earthquake production causes the majority of earthquake's energy to reach the structure as a long-period pulse. Therefore, near-field earthquakes produce many seismic needs so that they force the structure to dissipate output energy by relatively large displacements. Hence, in this paper, the seismic response of 5- and 8-story steel buildings equipped with special moment frames (SMFs) which have been designed based on type-II and III soils (according to the seismic code of Iran-Standard 2800) has been studied. The effects of soil-structure interaction and modeling of the panel zone were considered in all of the two structures. In order to model radiation damping and prevent the reflection of outward propagating dilatational and shear waves back into the model, the vertical and horizontal Lysmer-Kuhlemeyer dashpots as seen in the figures are adopted in the free-field boundary of soil. The selected near-and far-field records were used in the nonlinear time-history analysis, and structure response was compared in both states. The results obtained from the analysis showed that the values for the shear force, displacement, column axial force, and column moment force on typeIII soil are greater than the corresponding values on type-II soil; however, it cannot be discussed for drift in general.
\end{abstract}

\section{Introduction}

Over the past years, various design rules and seismic analysis for steel framed structures have been highly developed. Although most of the recent seismic design codes have taken up many of these developments, they are still described by some restrictions, with two of them being the most critical ones [1].

The first limitation has to do with the soil-structure interaction (SSI) phenomenon, which is disregarded by several seismic codes along with the regular everyday structural practice, presuming that lack of this phenomenon causes conservative outcomes [2-6]. In the related articles, several investigations approve the great impacts of SSI [7-11]. In this way, observations and examinations from real samples and also analyses have demonstrated that structures based on flexible soil display importantly other seismic responses than that of structures setup on solid rock caused by the substitution of the dynamic features of the system. The flexibility of soil resulted in a decline of stiffness, an increase in deformation, and to a rise in whole damping as a result of the radiation damping in the soil medium [12-14]. In addition, it 
should be taken into account that soft soil also affects the frequency content of the approaching seismic signals. Plus, the SSI phenomenon can result not only in positive but also in damaging consequences [15-17].

The second one with current seismic codes and design practice has to do with the traditional selection of far-field seismic ground motions to measure seismic design loads. This being said that a small number of norms and codes do consider, quantitatively and qualitatively, the seismic design of structures subjected to near-field records, for instance, FEMA P-750 [18]. Moreover, the powerful ground motions recorded near the fault zone and at stations placed in the direction of the fault rupture are qualitatively various from the usual far-field records [19].

The impacts of near-field and far-field ground motions on civil engineering structures have been studied in several past researches [20-24]. For the same ductility factor, the near-field ground motions inflict a greater strength demand than the far-field motions for SDF (single degree of freedom) systems [19]. Characterization of forward-directivity pulse motion of near-field earthquakes was named along with the fundamental parameters that contain amplitude (peak ground velocity), velocity pulse period, and the number of considerable cycles $[25,26]$.

In the direct method of analysis of soil-structure interaction (SSI), modeling both the underlying soil and the structure is needed exactly as they are to be analyzed with each other at the same time. The structure is a bounded medium and can be modeled to almost any practical level of validity at this time. On the other hand, two major barriers appear at the time of modeling the soil: its unlimited dimensions and its nonlinear behavior from very small strains. To eliminate the obstacle of limitlessness of soil medium, the soil is usually made restricted to a rigid bedrock at the bottom and two vertical artificial boundaries on the two sides. Based on the soil material behavior, in SSI analysis, usually the soil is presumed to act in a linear way but the stiffness and damping attributes of soil are altered to be steady with the moderate strain level in each layer. This approach is recognized as the equivalent linear method (ELM). Although the ELM has the significant benefit of highly simplifying the SSI analysis, it may not be appropriate to be used for the soil in the proximity of foundation, where the strain level is too high for the ELM to be adequately precise. However, this fact is often neglected and the ELM is applied for the whole soil medium [27].

Ghandil and Behnamfar [28] in their currently published article resolved the ELM barriers and suggested the nearfield method as an altered ELM with an additional decline of the soil shear modulus in the near-field zone that led to accuracy in adopting the ELM throughout. The current research establishes this new method as it can be suitable for a variety of structures and includes the impacts of various vibrational modes of the structure. In the first part of this article, a group of dimensionless parameters describing the corresponding properties of structure and soil consisting of the stiffness ratio $(s)$, the slenderness ratio $(h)$, and the mass ratio $(m)$ were chosen, and a comprehensive parametric study was accomplished to specify the Bull Earthquake Eng.
123 near-field zone dimensions and dynamic properties. Next, for calculating the near-field properties, semianalytical relations were suggested as functions of the dimensionless parameters [28]. Raychowdhury and Singh [27] examined the consequence of nonlinear soil-structure interaction (SSI) on the seismic responses of low-rise steel moment-resisting frame (SMRF) structures. In the situations where the soil below the foundation was presumed to be a system of closely spaced, independent, nonlinear spring elements, a Winklerbased method was selected. Nonlinear dynamic analyses and static pushover analysis were done on a 3-story SMRF building, and the efficiency of the structure was measured through a variety of force and displacement demand parameters. It was noticed that incorporation of nonlinear SSI results in a rise in story displacement demand and a drastic decrease in base moment, base shear, and interstory drift demands, showing the significance of its consideration towards achieving an economic, yet safe, seismic design.

In accordance with the performance-based design concept, Gerami and Abdollahzadeh [29] demonstrated the capability of steel moment frames exposed to near-field ground motions. In this regard, Dimakopoulou et al. [30] noticed the consequence of modeling hypothesis on the seismic response of structures under near-field records. The impact of forward directivity on collapse risk was also assessed by Champion and Liel [31]. In addition to that, Rahgozar et al. [32] managed a research on the behavior of self-centering braced frames which were subjected to nearfield ground motions.

This paper generally evaluates the seismic behavior of steel structures with a special moment frame system. This structural system was selected because of the engineers' expectation of high plasticity on the one hand and attention to the nature of the near-field earthquakes with progressive direction taking on the other. In this type of records, the structure does not have enough time to employ all its plasticity against the pulse-like behavior of these records due to the pulse-like behavior of the earthquake. In other words, these records act like a strong pulse in a short period on the structure, whereas we have high expectations from the special moment frame system. Moreover, the panel zone that has a significant impact on attenuation is modeled in order to adapt the models more to actual examples. Furthermore, the effects of soil-structure interaction (SSI) and the importance of changes created in the structure's seismic response due to the analysis of this behavioral set are generally nonnegligible. These effects may increase or decrease the seismic response of structures or their other seismic parameters under the force of the earthquake. These effects, in turn, depend on free-field dynamic properties of the structure (including the main vibration period and attenuation) and flexibility of the abutment. Similarly, it is possible that these changes cause changes in the force of the structural components (decrease or increase) and affect their safety, efficiency, or durability [15].

In Iran, the design code of resistant structures against earthquake (Standard No. 2800) [33] classified the bottom soil of foundation into four categories including types I, II, III, and IV based on the shear wave velocity $\left(V_{s}\right)$ at a depth of $30 \mathrm{~m}$ (Table 1). 
The structures in this research are located in Tehran, Iran, whose soil is normally of type II or type III according to the Iranian national building codes (Standard No. 2800). In comparison with soil type II, soil type III leads to obtaining a larger base shear for designing the structure in accordance with standard 2800; thus, sections will be larger. As a result, sometimes designers assume the soil has the structure type III regardless of soil mechanics reports when designing structures in type-II soil and design their structures based on this assumption. They consider this a more confident decision. However, the results of the present study prove this belief wrong.

\section{Numerical Modeling}

2.1. Selecting the Prototype Building Model. In this study, 5and 8 -story buildings are chosen. Figure 1 displays the studied architectural plan of the building with three bays, which are $5 \mathrm{~m}$ each, in each direction. The floor-to-floor height is equal to $3 \mathrm{~m}$.

The lateral resisting systems are the special momentresisting frames in $X$ and $Y$ directions. The buildings are residential in very high-risk zones on soil types II and III and are loaded and designed according to Iranian national building codes (Standard No. 2800). The dead and live loads of all stories are presumed to be $650 \mathrm{~kg} / \mathrm{m}^{2}$ and $200 \mathrm{~kg} / \mathrm{m}^{2}$, respectively. For the roof of the building, the loads are also equal to $450 \mathrm{~kg} / \mathrm{m}^{2}$ and $150 \mathrm{~kg} / \mathrm{m}^{2}$, respectively. The buildings with fixed bases are designed according to ACI318-05 in ETABS software. Therefore, the schematic view of the reference frames is depicted in Figure 2.

The cross-sections of the beams and columns for the second for the 5- and 8-story frames are shown in Tables 2 and 3.

The panel zone deforms primarily in shear due to the opposing moments in the columns and beams. The panel zone was explicitly modeled using the method of Gupta and Krawinkler [34] as a rectangle composed of eight very stiff elastic beam-column elements with one rotational spring to represent shear distortions in the panel zone. The Bilin material imitates the modified Ibarra-Medina-Krawinkler deterioration model with a bilinear hysteretic response [35].

The studied structures were modeled with elastic beamcolumn elements connected by rotational springs to represent the structure's nonlinear behavior. The springs follow a bilinear hysteretic response based on the Modified Ibarra Krawinkler Deterioration Model [36].

2.2. Modeling Soil-Structure Interaction. In this study, the direct method is employed for modeling SSI. Based on this method, structure and soil are modeled concurrently, and their responses are determined by analyzing the SSI system in each time step.

It should be noted that modeling of infinite soil media in soil-structure interaction plays a vital role. In the direct method of interaction analysis between soil and structure, the soil is modeled by the finite element method and the boundary conditions are implemented around the soil body. In this method, in addition to considering the geometrical
TABLE 1: Soil classification in Iranian national building codes [33].

\begin{tabular}{lcc}
\hline Soil types & $V_{\mathrm{s}}$ & $T_{\mathrm{s}}$ (fundamental period) \\
\hline Type I & $750 \leq V_{\mathrm{s}}$ & 0.4 \\
Type II & $375 \leq V_{\mathrm{s}} \leq 750$ & 0.5 \\
Type III & $175 \leq V_{\mathrm{s}} \leq 375$ & 0.7 \\
Type IV & $V_{\mathrm{s}} \leq 175$ & 1.0 \\
\hline
\end{tabular}

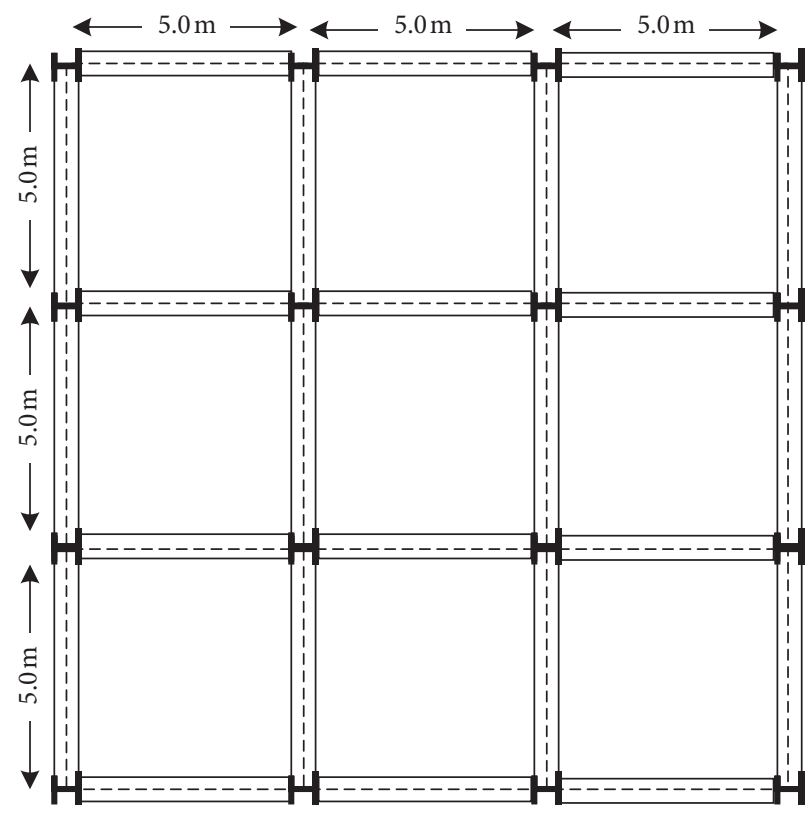

Figure 1: The plan view of the 5- and 8-story building.

damping, foundation burying and soil strata in horizontal and vertical directions may easily be modeled in the analysis [37]. In this method, there is a boundary limit obligation; thus, in order to consider the effect of energy distribution and its simulation, in direction of finite element boundaries, the primary boundaries are considered instead, in this research. These types of boundaries do not absorb energy, and for reduction of reflexive wave's effects, the distance between the structure and the boundaries must be increased [38].

For this purpose, modeling and obtaining the nonlinear dynamic responses of the SSI system are performed in the open-source finite element software OpenSees [35]. The finite element model of the SSI system adopted in this study is depicted in Figure 3.

The soil domain with the total length of $100 \mathrm{~m}$ and the depth of $30 \mathrm{~m}$ is modeled using isoparametric four-noded quadrilateral finite elements with two degrees of freedom per node. It is also assumed that the conditions of this domain are considered as plane strain with a constant crossplane thickness equal to the interframe distance. The modified pressure-independent multiyield surface $J_{2}$ plasticity model shown in Figure 4 is adopted as the constitutive model of the soil domain. Furthermore, some parameters of soil depend on the shear wave velocity of soil, $V_{s}$. In this study, the parameter $V_{s}$ for the soil types II and III is considered 400 and $275 \mathrm{~m} / \mathrm{s}$, respectively.

In order to model radiation damping and prevent the reflection of outward-propagating dilatational and shear 


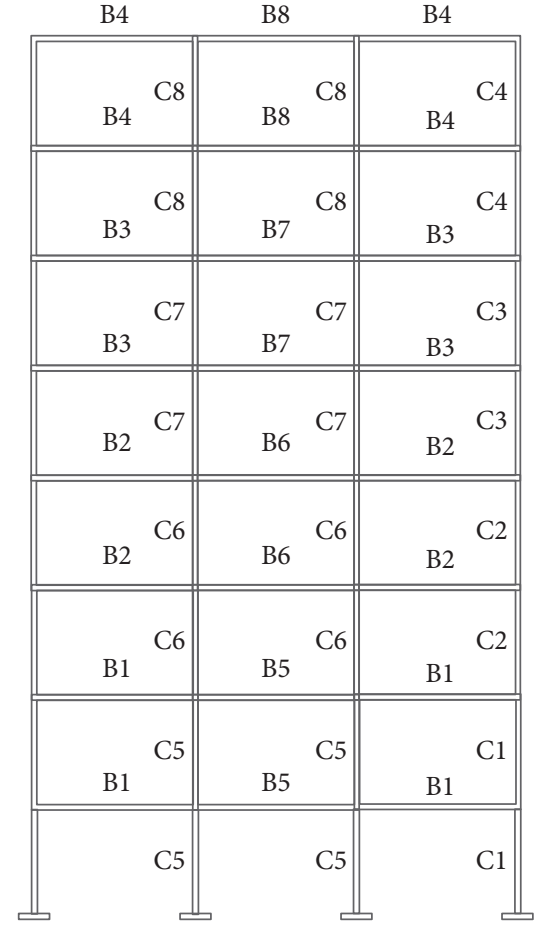

(a)

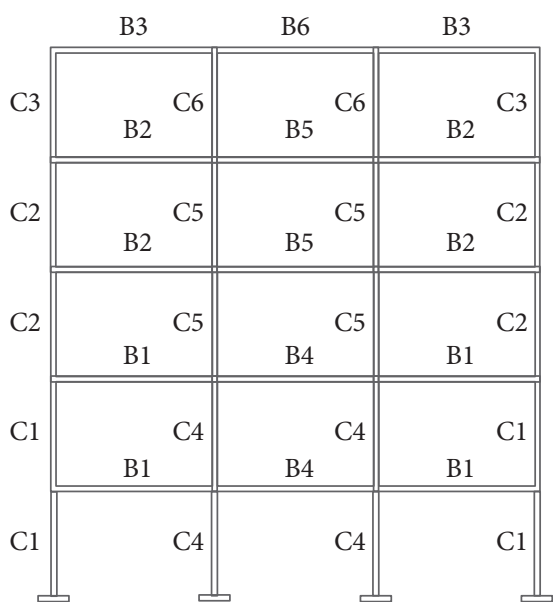

(b)

FIgURE 2: Topology and grouping details of (a) 8- and (b) 5-story frames.

TABLE 2: Designed sections of a 5-story structure.

\begin{tabular}{|c|c|c|c|c|}
\hline \multirow{2}{*}{$\begin{array}{l}\text { Type of } \\
\text { section }\end{array}$} & \multicolumn{2}{|l|}{ Soil II } & \multicolumn{2}{|l|}{ Soil III } \\
\hline & Column (length $*$ width $*$ thickness) mm & Beam & Column (length $*$ width $*$ thickness) $\mathrm{mm}$ & Beam \\
\hline $\mathrm{C} 1, \mathrm{~B} 1$ & Tube $240 * 240 * 20$ & $\mathrm{IPE} * 330$ & Tube $240 * 240 * 20$ & IPE 360 \\
\hline $\mathrm{C} 2, \mathrm{~B} 2$ & Tube $240 * 240 * 20$ & IPE 360 & Tube $240 * 240 * 20$ & IPE 360 \\
\hline $\mathrm{C} 3, \mathrm{~B} 3$ & Tube $180 * 180 * 20$ & IPE 240 & Tube $180 * 180 * 20$ & IPE 240 \\
\hline $\mathrm{C} 4, \mathrm{~B} 4$ & Tube $300 * 300 * 20$ & IPE 330 & Tube $340 * 340 * 20$ & IPE 400 \\
\hline $\mathrm{C} 5, \mathrm{~B} 5$ & Tube $300 * 300 * 20$ & IPE 360 & Tube $300 * 300 * 20$ & IPE 400 \\
\hline C6, B6 & Tube $240 * 240 * 20$ & IPE 240 & Tube $240 * 240 * 20$ & IPE 240 \\
\hline
\end{tabular}

$*$ European standard profiles.

TABle 3: Designed sections of a 8-story structure.

\begin{tabular}{|c|c|c|c|c|}
\hline \multirow{2}{*}{$\begin{array}{l}\text { Type of } \\
\text { section }\end{array}$} & \multicolumn{2}{|l|}{ Soil II } & \multicolumn{2}{|l|}{ Soil III } \\
\hline & Column (length $*$ width $*$ thickness) mm & Beam & Column (length $*$ width $*$ thickness) mm & Beam \\
\hline $\mathrm{C} 1, \mathrm{~B} 1$ & Tube $280 * 280 * 20$ & $\mathrm{IPE} * 400$ & Tube $340 * 340 * 20$ & IPE 450 \\
\hline $\mathrm{C} 2, \mathrm{~B} 2$ & Tube $280 * 280 * 20$ & IPE 400 & Tube $340 * 340 * 20$ & IPE 450 \\
\hline $\mathrm{C} 3, \mathrm{~B} 3$ & Tube $240 * 240 * 20$ & IPE 360 & Tube $280 * 280 * 20$ & IPE 450 \\
\hline $\mathrm{C} 4, \mathrm{~B} 4$ & Tube $180 * 180 * 20$ & IPE 330 & Tube $200 * 200 * 20$ & IPE 360 \\
\hline C5, B5 & Tube $400 * 400 * 20$ & IPE 400 & Tube $400 * 400 * 20$ & IPE 450 \\
\hline C6, B6 & Tube $340 * 340 * 20$ & IPE 450 & Tube $400 * 400 * 20$ & IPE 450 \\
\hline $\mathrm{C} 7, \mathrm{~B} 7$ & Tube $300 * 300 * 20$ & IPE 400 & Tube $340 * 340 * 20$ & IPE 450 \\
\hline $\mathrm{C} 8, \mathrm{~B} 8$ & Tube $240 * 240 * 20$ & IPE 360 & Tube $280 * 280 * 20$ & IPE 360 \\
\hline
\end{tabular}

*European standard profiles.

waves back into the model, the vertical and horizontal Lysmer-Kuhlemeyer dashpots as seen in Figure 4 are adopted in the free-field boundary of soil. The dashpots are modeled based on using a zero length element and the viscous uniaxial material. It is noted that more details of the Lysmer-Kuhlemeyer dashpot can be found in [40].
Furthermore, a raft foundation is considered as rigid and the connection between the soil and the structure is obtained using common nodes and appropriate constrains. The constraints are applied by equal DOF command in $X$ and $Y$ directions in order to ensure equal displacements for both the soil and the foundation of structure. 


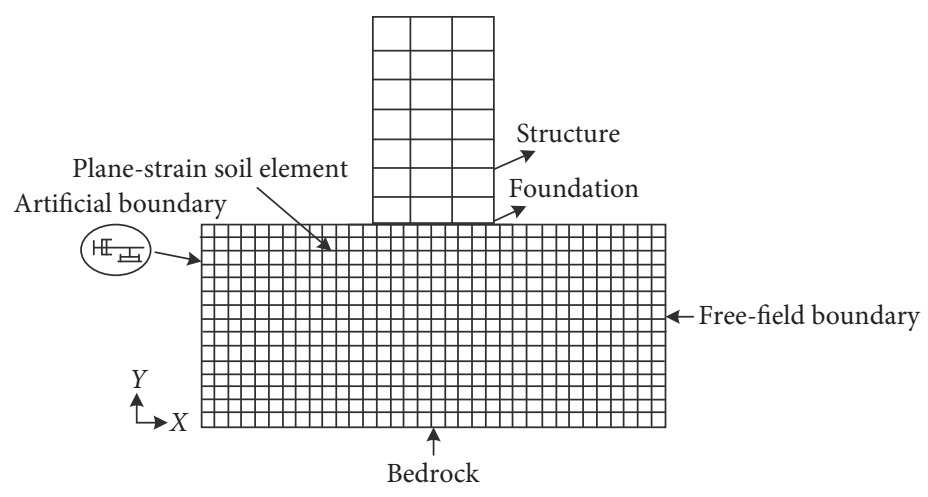

Figure 3: The finite element model of SSI system in OpenSees.

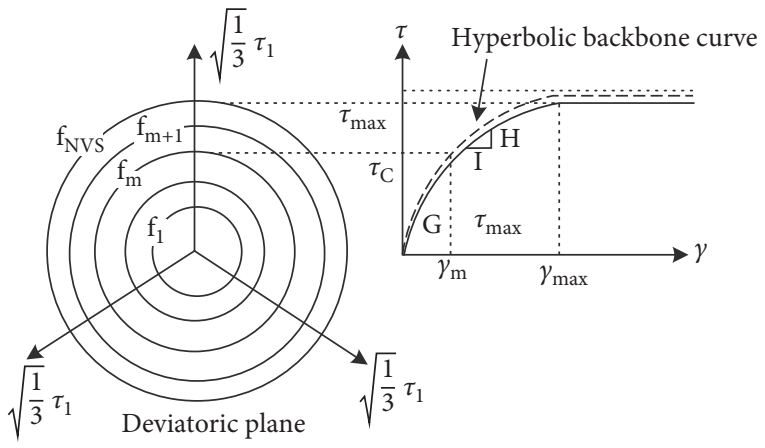

(a)

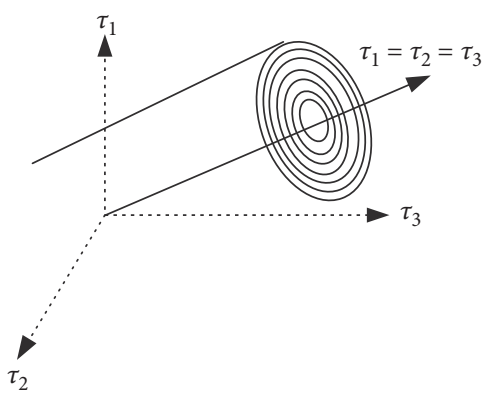

(b)

FIGURE 4: Yield surfaces of multiyield surface $J_{2}$ plasticity model: (a) octahedral shear stress-strain and (b) von Mises multiyield surfaces [39].

To observe the radiation damping by performing a numerical test, the nonlinearity in the soil and structure as well as any viscous damping simulated by the Rayleigh approach was temporarily eliminated, keeping only the viscous dashpots at boundaries. At this stage, a dynamic load is applied to the structure for a limited duration and the structure and soil response are observed for a certain time after the load ends. Since the structure and the soil are linear, and viscous damping is not included (temporarily), the energy inputted to the system is only dissipated through radiation; after the input ends, you should observe the elastic oscillation of the structure that is damped (displacements tend to vanish) due to geometric effects (radiation damping).

Past studies show that if the distance of the structure center to the soil finite element model boundaries is within 3-4 times of the foundation radius in the horizontal direction and 2-3 times of the foundation radius in the vertical direction, the influences of the reflexive waves are negligible $[37,41]$. In other words, the radiation condition is satisfied by considering nonreflecting boundaries simulated through dashpots, which means the model has included the radiation damping. Furthermore, there is hysteretic damping in the soil from the use of a nonlinear model.

As the typical damping ratios of the soils are between 3\% and $10 \%$ [42], a damping ratio of $5 \%$ is applied. Also, for the structure, $5 \%$ damping ratio is considered.

The fundamental period of the designed frames with and without the SSI effects is shown in Table 4. As seen from
Table 4, SSI effects are considered as the fundamental period of the designed frames.

Modeling the steel SMRF is considered using the lumped plasticity approach. In this approach, the beams and columns of the steel SMRF are modeled with elastic beamcolumn elements connected by zero length elements which serve as rotational springs to represent the nonlinear behavior of the structure. The rotational springs at the member ends follow a bilinear hysteretic response based on the Ibarra-Medina-Krawinkler (IMK) model [36]. Figure 5 represents the properties of the IMK model. As shown in Figure 5, using five parameters expressed in [43] can be completely taken into account for the nonlinearity in the model.

In the steel SMRF, the panel zone is deformed due to the shear force which is produced by the opposing moments in the beams and columns. To capture the deformation, the panel zone is considered in this study and explicitly modeled using the approach of Gupta and Krawinkler [34]. Based on this approach, a rectangular region is adopted and composed of eight very stiff elastic beam-column elements with one zero length element which serves as a rotational spring to represent shear distortions in the panel zone (see Figure 6).

\section{Near-Field Earthquakes of Fault Undergoing Forward Directivity}

In near-field earthquakes, the geometry position of fault relevant to the considered place is important beside the 
TABLE 4: The fundamental period of the designed frames.

\begin{tabular}{lccc}
\hline $\begin{array}{l}\text { Number } \\
\text { of stories }\end{array}$ & Soil type & \multicolumn{2}{c}{ Fundamental period $(s)$} \\
& & Without SSI & With SSI \\
\hline \multirow{2}{*}{5} & II & 0.76 & 0.86 \\
& III & 0.68 & 0.78 \\
8 & II & 0.91 & 1.08 \\
& III & 0.88 & 0.91 \\
\hline
\end{tabular}

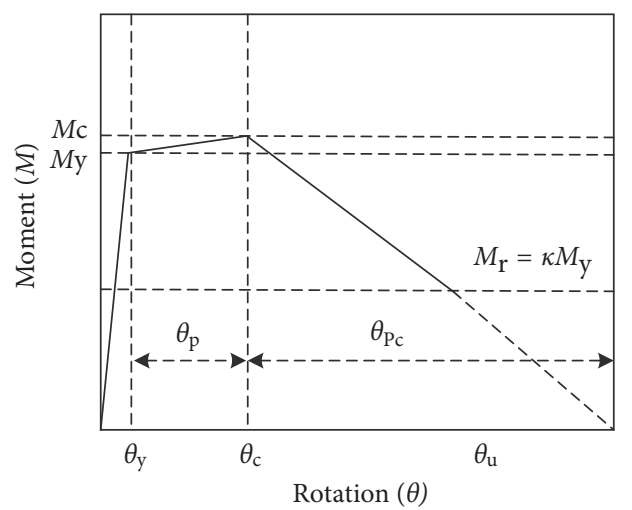

Figure 5: Monotonic moment-rotation relationship for the modified IMK deterioration model [36].

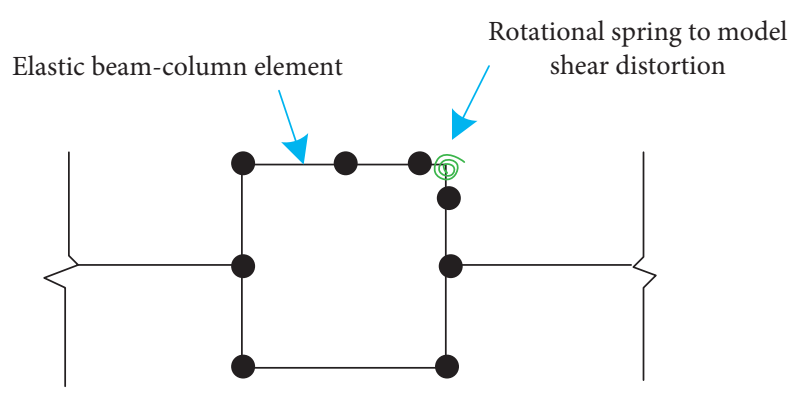

FIGURE 6: Schematic representation of a typical panel zone.

rupture mechanism and kind of faulting. The amplitude of this pulse depends on the directivity of rupture propagation to the site. Since the rupture propagation velocity is nearly equal to the velocity of shear wave propagation, if the fault rupture spreads to the considered place, the waves in a shortterm period will reach to the place, causing a pulse with high amplitude and long period, which is called forward-effect directivity. Now, if the rupture is in a direction of getting away from the site, the waves will scatteredly reach the spot which is defined backward directivity, whereas the rupture directivity neither close to the location nor far is called neutral directivity [44]. Pulse motion can also be produced by permanent displacement of ground caused by surface rupture.

What has been examined in this paper is the effect of pulse caused by forward directivity that, according to the obtained results of previous researches, exerts the most extensive damage to the structure $[45,46]$. This angle is small in nature and is shown in Figure 7.
3.1. Selecting of Ground Motions. The random nature of earthquakes has been a challenging problem in the seismic evaluation of structures and has converted this evaluation to a probabilistic problem. Hence, in this study, 14 real ground motion records are selected from the PEER-NGA database. The properties of these records are indicated in Tables 5 and 6.

It is noted that the ground motion records shown in Tables 5 and 6 are selected based on $V_{\mathrm{S}} \geq 750 \mathrm{~m} / \mathrm{s}$ (i.e., bedrock condition) in order to obtain the ground motion records based on the soil types II and III according to Iranian national building code [33].

In time-history analyses, choosing a suitable record in order to evaluate structures is of utmost importance. Hence, in this study, 14 real ground motion records are selected from the PEER-NGA database. The properties of these records are indicated in Tables 5 and 6 . In this research, 7 earthquake records related to near-field undergoing forward directivity and 7 records of far-field earthquakes have been selected in order to analyze nonlinear time-history analyses. Far-field earthquakes have been recorded in a distance of $60 \mathrm{~km}$ from the fault. The magnitude of these records ranges from 6.5 to 7.2. The magnitude of near-field earthquakes ranges from 6.61 to 7.51 , being recorded in a distance of $10 \mathrm{~km}$ from fault. It is noted that the ground motion records shown in Tables 5 and 6 are selected based on $V_{\mathrm{S}} \geq 750 \mathrm{~m} / \mathrm{s}$ (i.e., bedrock condition).

It should be noted that, in the direct approach, the whole system of soil and structure should be vibrated, so ground motions are applied to the bedrock, which is assumed to be at a certain depth under the soil system (Figure 8). Hence, it is clear that the ground motions are related to the bedrock. When the soil under the structure is considered as the type III, in the modeling process, the properties of this type of soil (e.g., shear wave velocity) are assigned. For example, in [38], regarding the selection of the ground motion, the soil type I (based on EC8) was selected in SSI analysis.

The ground motions were scaled such that the average value of their square root of the sum of the squares (SRSS) spectra does not fall below 1.4 times the Standard Design Spectra for periods of $0.2 \mathrm{~T}$ second to $1.5 \mathrm{~T}$ seconds, where $T$ is the fundamental period of vibration [33]. Figure 9 shows the scaling procedure for the 8-story building under near-field records.

\section{Evaluation of Seismic Response of Structures}

One of the most important steps in seismic design is the estimation and control of structure's drift, causing stable increase of the whole building during an earthquake. In addition, confining lateral displacement of the structure decreases the damage of nonstructural elements such as mechanical equipment and architectural elements.

Moreover, the relative displacement of the stories can be a criterion for the calmness of the dwellers against displacement originated from wind load as well as structural damage. Investigations have revealed that the angle value of relative displacement of the stories can demonstrate the 


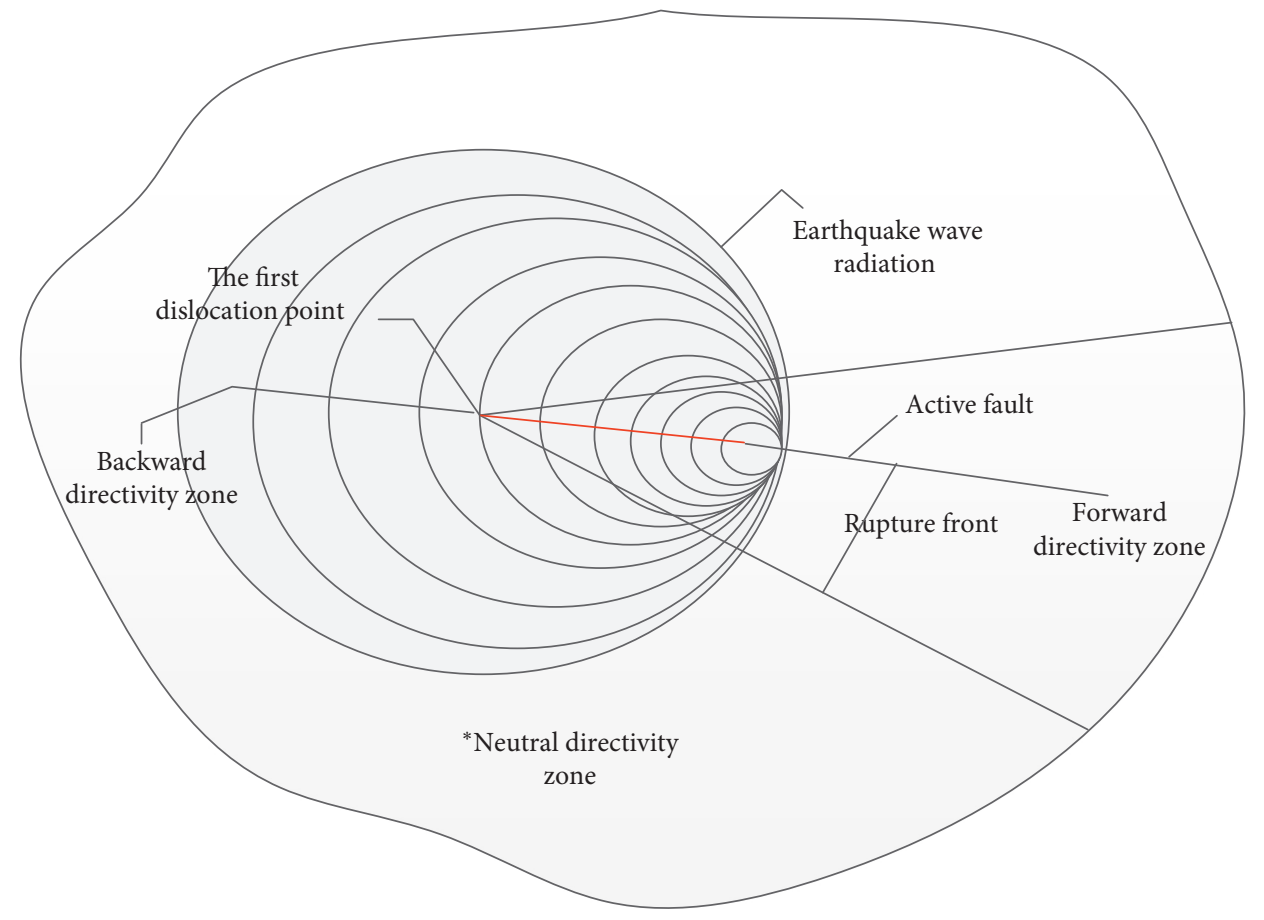

FIGURE 7: Forward, backward, and neutral directivity zones in a region near to an active fault [47].

TABLE 5: Far-fault ground motion records.

\begin{tabular}{|c|c|c|c|c|c|c|c|c|c|c|c|}
\hline No. & Year & Earthquake & Station & $\begin{array}{c}V_{\mathrm{s}} 30 \\
(\mathrm{~m} / \mathrm{sec})\end{array}$ & Comp. & Mechanism & $\mathrm{Mw}$ & $\begin{array}{c}\text { PGA } \\
(\mathrm{g})\end{array}$ & $\begin{array}{l}\text { PGV } \\
(\mathrm{m} / \mathrm{s})\end{array}$ & $\begin{array}{l}\text { PGD } \\
(\mathrm{cm})\end{array}$ & $\begin{array}{c}\mathrm{R} \\
(\mathrm{km})\end{array}$ \\
\hline 1 & 2003 & an & iablo Can & 1100 & $\mathrm{H}$ & $\operatorname{Re}$ & 6 & 0.046 & 0.087 & 5.55 & 37.92 \\
\hline 2 & 999 & Duzce_Turk & Lamont & 78 & $\mathrm{E}$ & Strik & & & & & 25.78 \\
\hline 3 & 2004 & Niigata_Japan & FKSH07 & 828 & NS & Reverse & 6.63 & 43 & 3 & 29 & 52.15 \\
\hline 4 & 1999 & $\begin{array}{c}\text { Chi-Chi_Taiwan- } \\
06\end{array}$ & HWA002 & 789.18 & $\mathrm{~N}$ & Rev & 6. & 0.032 & 0.03 & 1.36 & 47.81 \\
\hline s & 00 & Iwate_Japan & & & & & & & & 4 & 40.42 \\
\hline 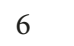 & 1971 & San Ferna & 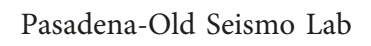 & (30 & 270 & & 6.61 & 0.204 & 0 . & 1.35 & 21.5 \\
\hline 7 & 1994 & Northridge-01 & Vasquez Rocks Park & 996.43 & 0 & Reverse & 6.69 & 0.151 & 0.183 & 2.84 & 23.1 \\
\hline
\end{tabular}

TABLE 6: Near-field ground motion records.

\begin{tabular}{|c|c|c|c|c|c|c|c|c|c|c|c|}
\hline No. & Year & Earthquake & Station & $\begin{array}{c}V_{\mathrm{s}} 30 \\
(\mathrm{~m} / \mathrm{sec})\end{array}$ & Comp. & Mechanism & $\mathrm{Mw}$ & $\begin{array}{c}\text { PGA } \\
(\mathrm{g})\end{array}$ & $\begin{array}{l}\text { PGV } \\
(\mathrm{cm} / \mathrm{s})\end{array}$ & $\begin{array}{l}\text { PGD } \\
(\mathrm{m})\end{array}$ & $\begin{array}{c}\mathrm{R} \\
(\mathrm{km}) \\
\end{array}$ \\
\hline 1 & 1995 & Kobe & Kobe University & 1043 & 90 & Strike slip & 6.9 & 0.311 & 30.88 & 0.074 & 0.9 \\
\hline 2 & 1999 & Kocaeli & Gebze & 792 & 0 & Strike slip & 7.51 & 0.26 & 44.62 & 0.41 & 7.75 \\
\hline 3 & 1992 & Landers & Lucerne & 1369 & 345 & Strike slip & 7.28 & 0.788 & 56.21 & 1.021 & 2.19 \\
\hline 4 & 1989 & Loma prieta & Lexington Dam, Los Gatos & 1070 & 0 & Reverse oblique & 6.93 & 0.442 & 85.69 & 0.1733 & 3.22 \\
\hline 5 & 1989 & Loma prieta & Gilroy Array\#1 & 1428.14 & 1090 & Reverse oblique & 6.93 & 0.484 & 32.48 & 0.156 & 8.84 \\
\hline 6 & 1994 & Northridge-01 & Pacoima Dam (Downstr) & 2016.13 & PAC265 & Reverse & 6.69 & 0.433 & 30.11 & 0.054 & 4.92 \\
\hline 7 & 1971 & San Fernando & Pacoima Dam (upper left abut) & 2016.13 & 254 & Reverse & 6.61 & 1.238 & 57.27 & 0.128 & 0 \\
\hline
\end{tabular}

performance of structural and nonstructural elements in a way that if this angle is 0.001 , the nonstructural damages would be possible; if the value of this parameter reaches 0.007 , the possibility of nonstructural damages would be certain and structural damages would be possible. On the other hand, if the angle value of relative displacement exceeds 0.015 , the nonstructural damages will occur and structural damages would be possible. Another reason to confine drift is secondary effects such as $\mathrm{P}-\Delta$, particularly in the near-field (Naeim, F (2001)).

After investigating the results obtained from nonlinear time-history analysis, it was specified that in near-field earthquakes, the maximum story drift ratio in type-II soil in 5- and 8-story buildings are 0.025 and 0.024 , respectively (under the effect of Sanfernando record), and in type-III soil are 0.024 and 0.019 (under the effect of Loma Prieta Los 


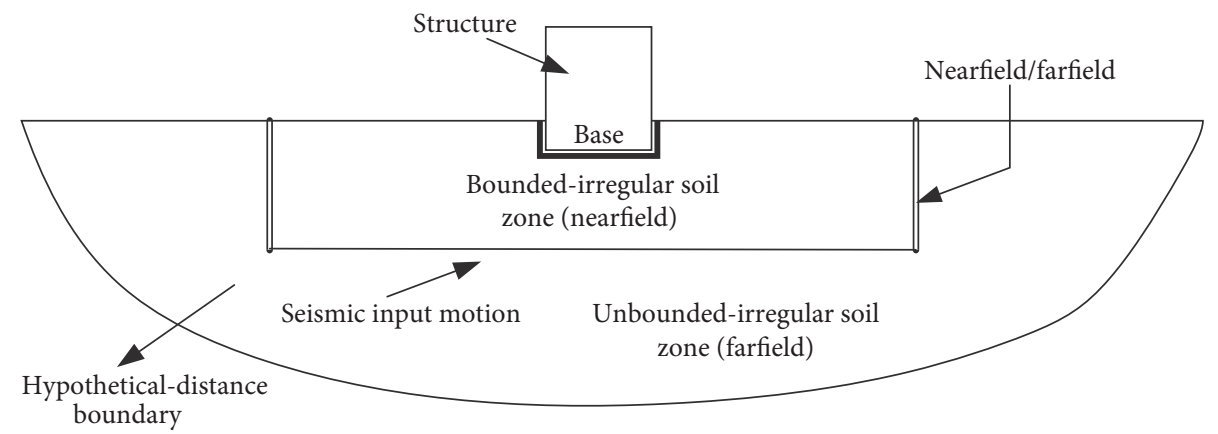

Figure 8: Components of a system of soil and structure interaction [48].

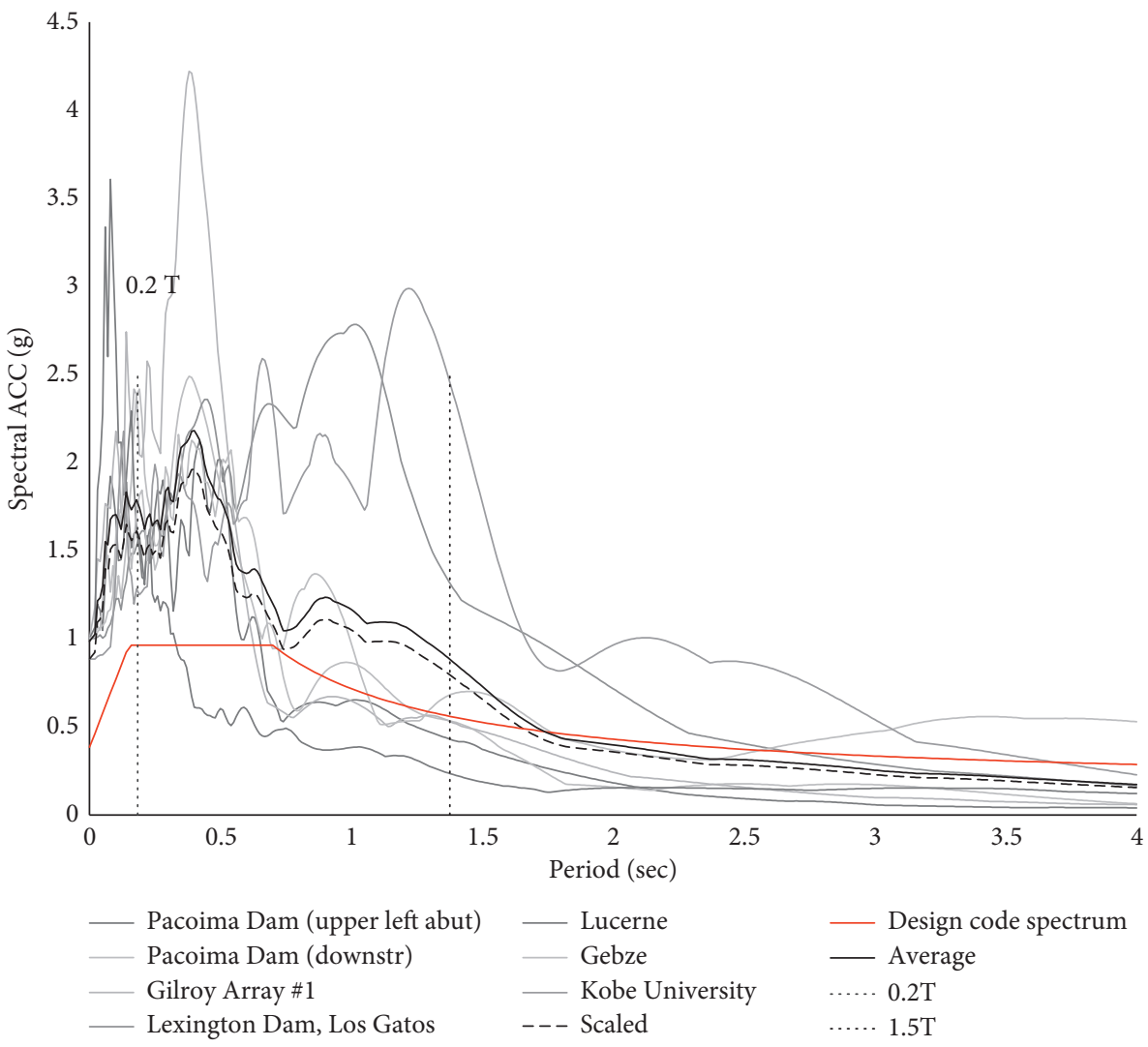

FIGURE 9: Elastic response spectral acceleration and scaling procedure.

Gatos record). As shown, the maximum drift ratio in 5-story structure, constructed on type-II soil, was $5 \%$ more than the maximum drift ratio in type-III soil. Also, the maximum drift ratio in 8 -story building in type-II soil was $23.2 \%$ greater than the maximum drift ratio in type-III soil. The results obtained from the two mentioned structures indicated that the maximum drift imposed to the structures in type-II soil is greater than that in type-III soil which is set to augment as the number of stories increase. The changes of maximum drift ratio in the mentioned structures can be seen for all records in Figure 10.

In Table 7, it has been shown that, on average, the maximum drift ratio of 5- and 8-story structures in type-II soil is equal to the average maximum drift ratio of 5- and 8story structures on type-III soil.
Another critical parameter in structure design is the shear force of the stories. According to the obtained results, it can be said that the maximum shear force of stories subjected to near-field earthquakes in 5- and 8-story buildings on type-II soil are $123.38 \mathrm{kN}$ (under Loma Prieta Gilroy Array record) and $297.81 \mathrm{kN}$ (under San Fernando record). Also, this parameter for 5- and 8-story buildings on type-III soil is $125.49 \mathrm{kN}$ and $332.48 \mathrm{kN}$, respectively. Based on these results, the maximum shear force in a 5 -story building on type-II soil is $2 \%$ lower than the maximum shear force on type-III soil. Also, for 8-story building, this discrepancy is approximately $11 \%$. The classification effect of the site's soil on the base shear force of structure is insignificant in a 5-story building, whereas by changing the soil type from II to III, the base shear force increases in 8-story buildings. 

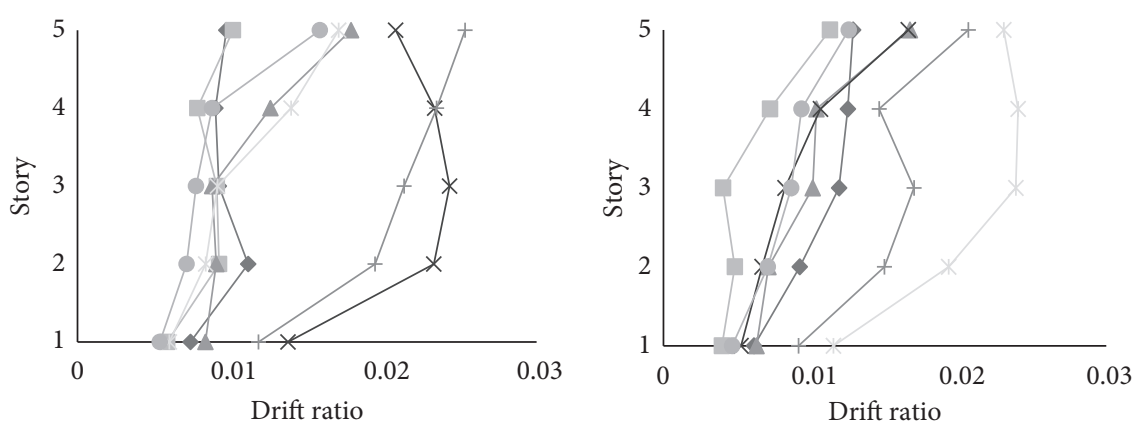

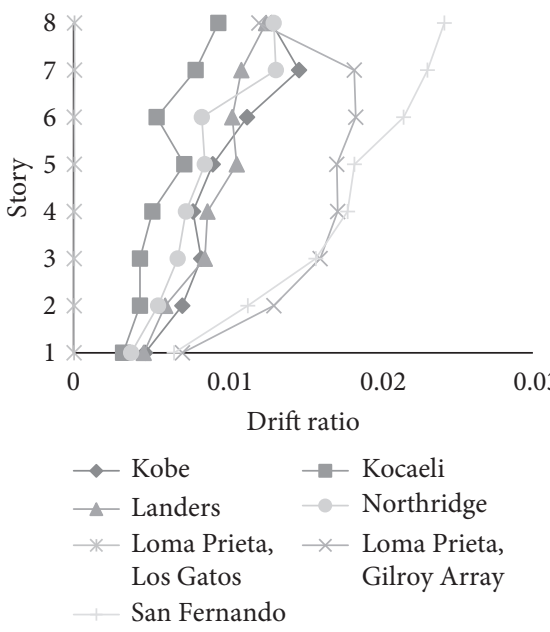

(a)
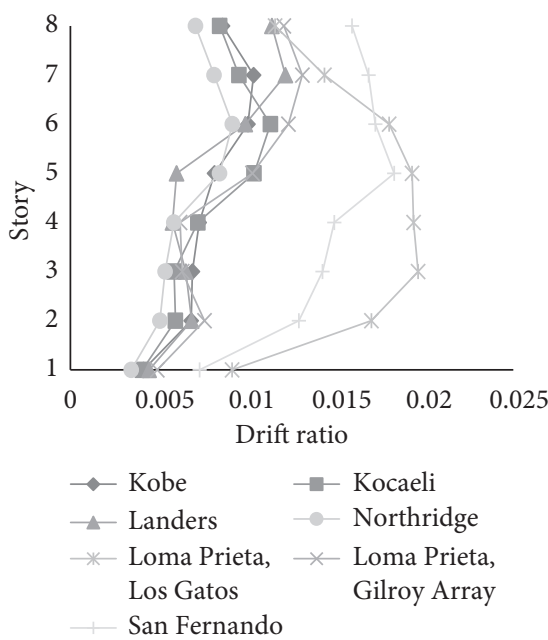

(b)

FIgURe 10: Maximum drift ratio variations of 5- and 8-story frames under near-field records. (a) Soil type II and (b) soil type III.

TABLE 7: Average of maximum drift ratio under near-field records.

\begin{tabular}{lccc}
\hline Story & Soil II & Soil III & Ratio (II/III) \\
\hline 5 & 0.02 & 0.02 & 1 \\
8 & 0.013 & 0.013 & 1 \\
\hline
\end{tabular}

According to Table 8, it can be said that, on average, the maximum shear force of the stories in 5- and 8-story buildings on type-II soil are $3 \%$ and $11 \%$ less than the 5 - and 8 -story buildings on type-III soil. Shear force changes of the stories can be observed in Figure 11.

The third important evaluated parameter is the displacement of the stories. The maximum displacements of stories subjected to near-field earthquakes in 5- and 8story structures on type-II soil are $303.3 \mathrm{~mm}$ and $326.7 \mathrm{~mm}$, respectively. In 5- and 8-story structures, the maximum displacements of stories have increased and these values are $334.7 \mathrm{~mm}$ and $387.7 \mathrm{~mm}$. In 5- and 8story buildings in both type soils Loma Prieta Gilroy Array record and San Fernando record resulted in these values. As shown, the maximum displacements of 5- and 8 -story structures on type-II soil are $10 \%$ and $8 \%$ lower than the amount of this parameter on type-III soil. The results show that the site change from type-II soil to typeIII soil imposes higher displacement on stories. In Figure 10 , the maximum and average displacements have been given.
TABLE 8: Average of shear story under near-field records.

\begin{tabular}{lccc}
\hline Story & Soil II $(\mathrm{kN})$ & Soil III $(\mathrm{kN})$ & Ratio $(\mathrm{II} / \mathrm{III})$ \\
\hline 5 & 112.64 & 115.94 & 0.97 \\
8 & 269.94 & 300.32 & 0.89 \\
\hline
\end{tabular}

Based on Figure 12, the maximum and average displacements of the 8-story structure on type-II soil are greater than those of type-III soil.

According to Table 9, the average maximum displacement of 5-story structure on type-II soil in relations to typeIII soil has been increased to about $13 \%$, whereas this value in 8-story buildings on type-II soil compared with type-III soil has decreased to around $12 \%$.

Of the other seismic parameters evaluated in this paper are axial forces and moments in columns.

The maximum axial force produced in columns subjected to near-field earthquakes in 5- and 8-story structures on type-II soil is $11.12 \mathrm{kN}$ and $21.56 \mathrm{kN}$. On the other hand, the maximum axial force created in the columns of 5- and 8 -story buildings on type-III soil is $12.63 \mathrm{kN}$ and $22.84 \mathrm{kN}$, respectively. This value in 5- and 8-story buildings on typeII soil occurred in C12 (the position of the columns in the frames is shown in Figure 13) and C13 columns under the Landers record. Also, for type-III soil, this parameter for 5and 8-story structures occurred in $\mathrm{C} 12$ and C13 columns under San Fernando record. It can be concluded that the 

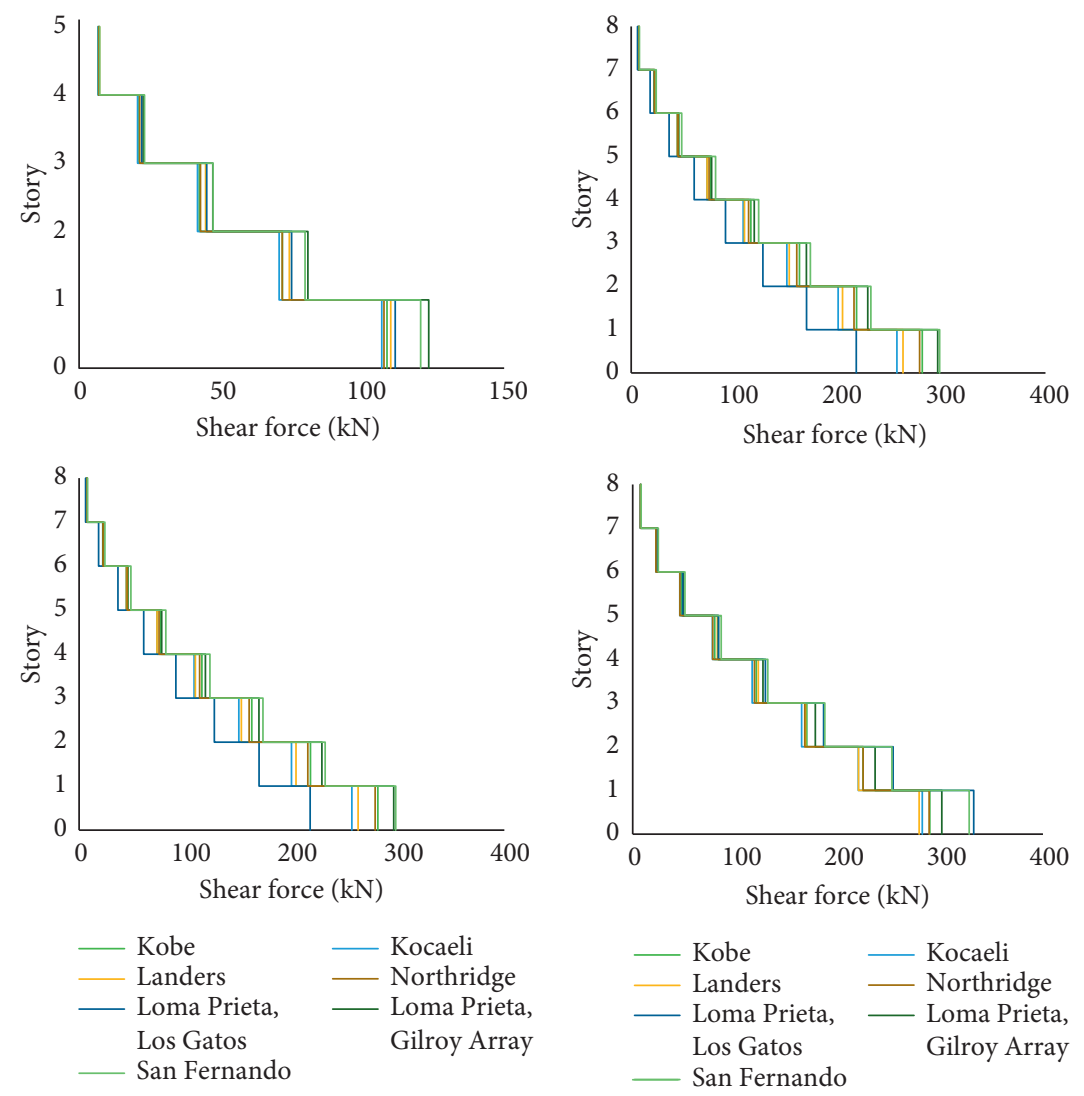

(a)

(b)

FIGURE 11: Shear story variations of 5- and 8-story frames under near-field records. (a) Soil type II and (b) soil type III.

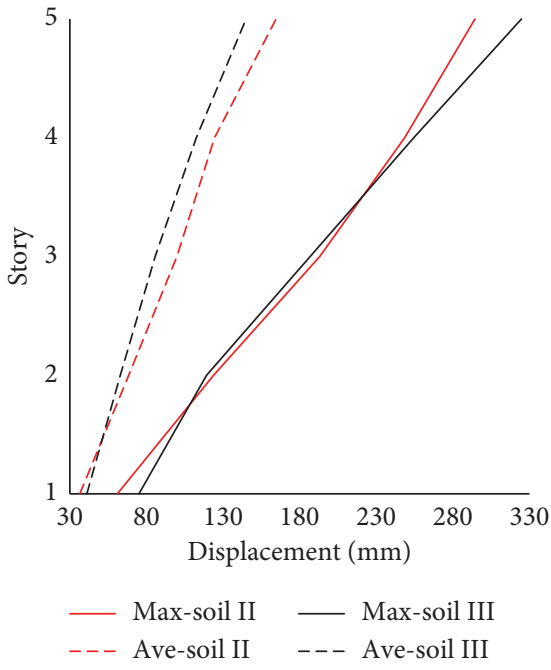

(a)

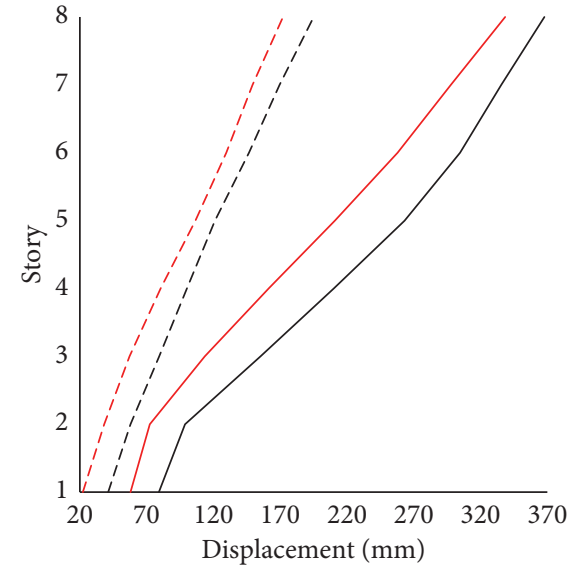

- Max-soil II _ Max-soil III

- - - Ave-soil II _ - - Ave-soil III

(b)

FIgURe 12: Maximum floor displacement variations of (a) 5-story and (b) 8-story frames under near-field records.

TABLE 9: Average of maximum floor displacement under near-field records.

\begin{tabular}{lccc}
\hline Story & Soil II $(\mathrm{mm})$ & Soil III $(\mathrm{mm})$ & Ratio (II/III) \\
\hline 5 & 169.13 & 148.89 & 1.13 \\
8 & 180.81 & 205.09 & 0.88 \\
\hline
\end{tabular}

maximum axial force of the columns in the 5-story structure on type II soil is $12 \%$ lower than that in a 5 -story structure on type-III soil. This was also seen for 8-story buildings. The maximum axial force caused on type-II soil was $6 \%$ lower than that on type-III soil. According to this, the maximum axial force produced in columns of the 


\begin{tabular}{|c|c|c|}
\hline $\mathrm{C} 8_{1}$ & $\begin{array}{ll}C 8_{2} & C 8_{3}\end{array}$ & $\mathrm{C}_{4}$ \\
\hline $\mathrm{C}_{1}$ & $\begin{array}{ll}\mathrm{C}_{2} & \mathrm{C}_{3}\end{array}$ & $\mathrm{C}_{4}$ \\
\hline $\mathrm{C} 6_{1}$ & $\mathrm{C6}_{2} \mathrm{C6}_{3}$ & $\mathrm{C}_{4}$ \\
\hline $\mathrm{C} 5_{1}$ & $\begin{array}{ll}\mathrm{C}_{2} & \mathrm{C} 5_{3}\end{array}$ & $\mathrm{C}_{4}$ \\
\hline $\mathrm{C} 4_{1}$ & $\mathrm{C}_{2} \quad \mathrm{C}_{3}$ & $\mathrm{C}_{4}$ \\
\hline $\mathrm{C} 3_{1}$ & $\mathrm{C} 3_{2} \quad \mathrm{C}_{3}$ & $\mathrm{C}_{4}$ \\
\hline $\mathrm{C} 2_{1}$ & $\mathrm{C} 2_{2} \quad \mathrm{C} 2_{3}$ & $\mathrm{C} 2_{4}$ \\
\hline $\mathrm{C} 1_{1}$ & $\| \begin{array}{ll}\mathrm{Cl}_{2} & \mathrm{Cl}_{3}\end{array}$ & $\mathrm{Cl}_{4}$ \\
\hline
\end{tabular}

(a)

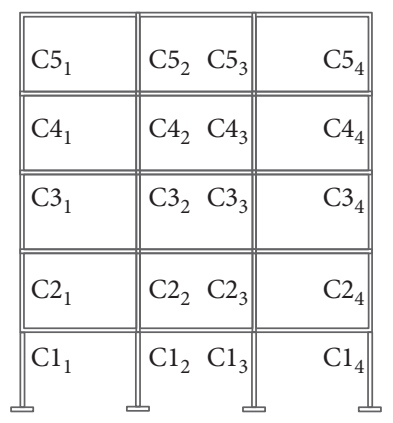

(b)
FIGURE 13: Column section numbering: (a) 8-story frame and (b) 5story frame.

structure is weaker than the corresponding values in typeIII soil.

The maximum moment produced in columns of 5- and 8-story structures subjected to near-field earthquakes on type-II soil that occurred under Loma Prieta Gilroy Array record is $9.29 \mathrm{kN} \cdot \mathrm{m}$ and $11.72 \mathrm{kN} \cdot \mathrm{m}$. The maximum moment created in columns of 5- and 8-story structures on type-III soil which was obtained under the Loma Prieta Los Gatos record is $11.63 \mathrm{kN} \cdot \mathrm{m}$ and $14.90 \mathrm{kN} \cdot \mathrm{m}$. According to the obtained results, it can be said that the maximum moment created in a 5 -story building on type-II soil is $21.2 \%$ lower than that in type-III soil. Also, this value for the 8story building is about $22.2 \%$. A comparison of the results reveals that the maximum moment in both 5- and 8-story structures on type-III soil is stronger than the corresponding values on type-II soil.

According to Table 10, it can be said the average maximum axial forces of 5- and 8-story structures on type II are $14 \%$ and $20 \%$ lower than the average maximum axial forces on type-III soil, respectively. Also, the average maximum produced moment in a 5-story building on typeII soil is $17 \%$ lower than the created moment on type-III soil. This also is $24.2 \%$ for type-III soil.

4.1. Seismic Evaluation of Structures Subjected to Far-Field Earthquakes. After investigating obtained results of nonlinear time-history analysis subjected to far-field earthquakes records, it was specified that the maximum drift ratios in 5- and 8-story structures on type-II soil are 0.014 and 0.012 (under the San Fernando earthquake record), respectively. These values are 0.02 and 0.01 on type-III soil which occurred under the effect of San Fernando earthquake record. In 5-story structure on type-II soil, the maximum drift ratio is $30 \%$ lower than the maximum drift ratio on type-III soil. This value for the 8 -story structure is $20 \%$ greater than that on type-III soil.
TABle 10: Average of maximum column force under near-field records.

\begin{tabular}{lcccccc}
\hline \multirow{5}{*}{ Story } & \multicolumn{3}{c}{ Column axial force $(\mathrm{kN})$} & \multicolumn{3}{c}{ Column moment force $(\mathrm{kN} \cdot \mathrm{m})$} \\
& Soil II & Soil III & $\begin{array}{c}\text { Ratio } \\
(\mathrm{II} / \mathrm{III})\end{array}$ & Soil II & Soil III & $\begin{array}{c}\text { Ratio } \\
(\mathrm{II} / \mathrm{III})\end{array}$ \\
\hline 5 & 9.11 & 10.51 & 0.86 & 6.24 & 7.46 & 0.83 \\
8 & 15.83 & 19.59 & 0.80 & 7.55 & 9.85 & 0.76 \\
\hline
\end{tabular}

Figure 14 gives information about drift changes in the mentioned structures for all records.

According to Table 11, on average, the maximum drift ratios of 5- and 8-story structures on type-II soil are equal to the maximum drift ratios on type-III soil.

San Fernando records reveal that the maximum shear force of stories subjected to far-field earthquakes in 5- and 8 -story structures on type-II soil are $105.15 \mathrm{kN}$ and $257.34 \mathrm{kN}$, respectively. These values on type-III soil are $112.40 \mathrm{kN}$ and $278.34 \mathrm{kN}$ (under the San Fernando record). Based on the data, it can be expressed that the maximum shear force in 5-story buildings on type-II soil is 7\% lower than that on type-III soil; the figure that increased to $8 \%$ in 8 -story buildings. Site's soil classification changing from type II to III makes the base shear force of both structures augmented.

Figure 15 illustrates the changes in the shear force of the structure. Table 12 shows that, on average, the maximum shear forces of 5- and 8-story structures on type II are 6\% and $5 \%$ lower than those on type-III soil.

The maximum displacements of stories' subjected to farfield earthquakes in 5- and 8-story buildings on type-II soil are $74.15 \mathrm{~mm}$ and $95.03 \mathrm{~mm}$, respectively. In 5- and 8-story structures constructed on type-III soil, these values increased and were $120.8 \mathrm{~mm}$ and $102.56 \mathrm{~mm}$ (under San Fernando record), respectively. As it can be seen, the maximum values of displacement in 5- and 8-story structures on type-II soil are 39\% and 7\% lower than those on type-III soil. Figure 16 manifests the comparison of the maximum changes and average displacement of stories.

According to Table 13, it can be said that the average maximum of stories' displacement in 5- and 8-story structures on type-II soil in relation to type-III soil is about $29 \%$ more and around $7 \%$ less, respectively.

The maximum axial force produced in columns subjected to the far-field earthquake in 5 - and 8-story buildings on type-II soil are $9.4 \mathrm{kN}$ and $16.80 \mathrm{kN}$. These values are $10.90 \mathrm{kN}$ and $18.35 \mathrm{kN}$ on type-III soil, respectively. Meanwhile, the maximum values of axial force in 5- and 8story structures on type-III soil occurred in the $\mathrm{C} 13 \mathrm{col}$ umn. However, in type-II soil, this occurred in C12 and C13 columns for 5- and 8-story structures, respectively (San Fernando record in types II and III). It can be concluded that the maximum axial force of columns in the 5story structure on type-II soil is $14 \%$ lower than that on type-III soil, whereas for 8-story building, this value for type-II soil is $9 \%$ lower than that in type-III soil. The results show that the maximum produced axial force in columns on type-II soil is weaker than the corresponding values on type-III soil. 

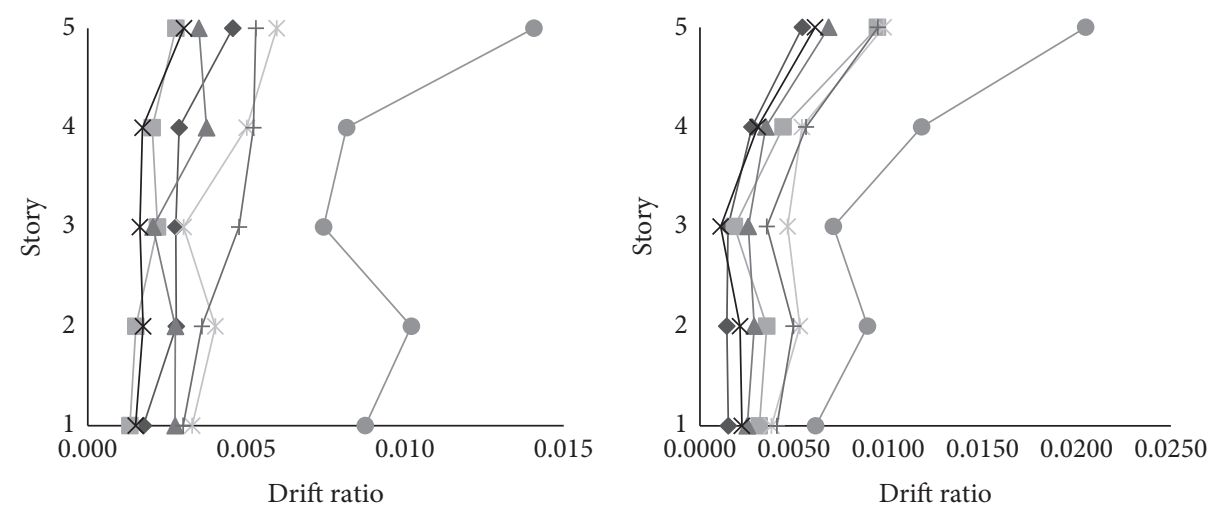

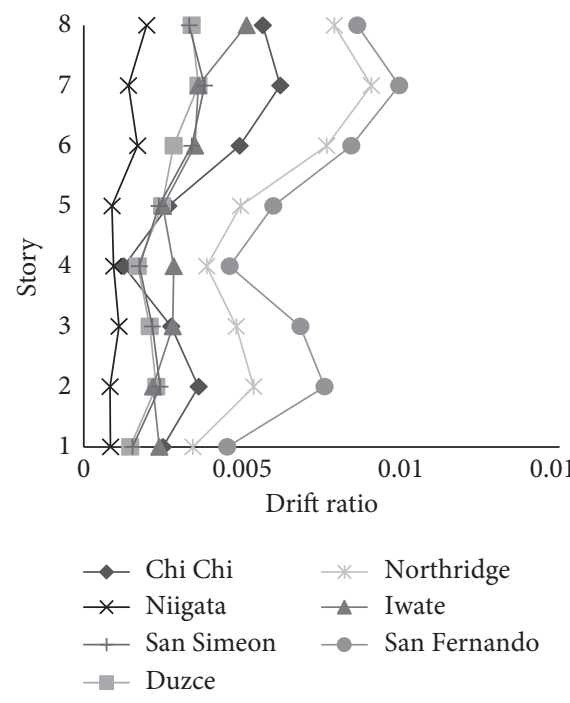

(a)

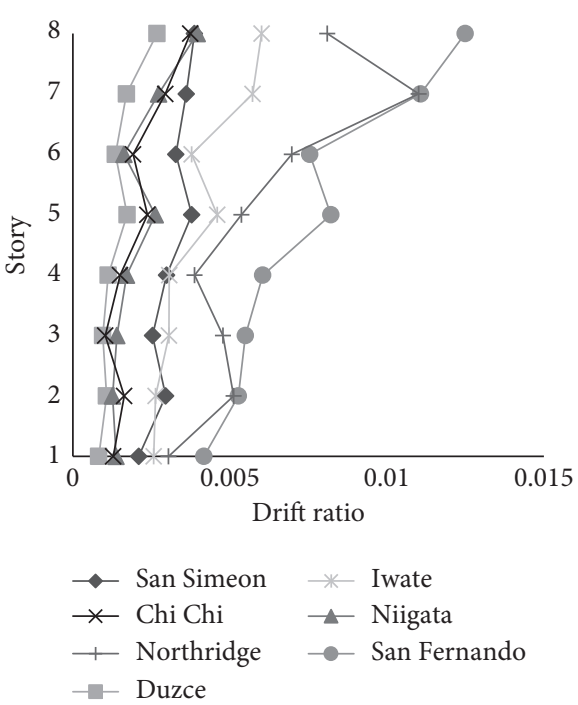

(b)

Figure 14: Maximum drift ratio variations of 5- and 8-story frames under far-field records. (a) Soil type II and (b) soil type III.

TABLE 11: Average of maximum drift ratio under far-field records.

\begin{tabular}{lccc}
\hline Story & Soil II & Soil III & Ratio (II/III) \\
\hline 5 & 0.01 & 0.01 & 1 \\
8 & 0.01 & 0.01 & 1 \\
\hline
\end{tabular}

The maximum caused moment in the columns of 5- and 8-story buildings subjected to far-field earthquakes on typeII soil are $6.73 \mathrm{kN} \cdot \mathrm{m}$ and $7.94 \mathrm{kN} \cdot \mathrm{m}$ respectively. Meanwhile, for type-III soil, in 5- and 8-story structures, these parameters are $7.34 \mathrm{kN} \cdot \mathrm{m}$ and $8.13 \mathrm{kN} \cdot \mathrm{m}$ respectively (San Fernando record in types II and III). Based on the obtained results, it can be said that the created moment on type-II soil for the 5-story structure is $8 \%$ lower than that on type-III soil. Also, this value in 8 -story buildings on type-II soil is $25 \%$ lower than that on type-III soil.

According to the given results in Table 14, it can be said that the average maximum axial force in 5- and 8-story structures on type-II soil are $21 \%$ and $10 \%$ lower than the average maximum axial force in type-III soil. On the other hand, the average maximum axial force in the 5-story structure on type-II soil is $32 \%$ lower than that on type-III soil. This value on type-II soil in the 8 -story buildings is $4 \%$ lower than that on type-III soil.
To summarize the results, in Table 15 and Table 16, the comparative results between near- and far-field ground motions are listed.

The careful examination of the values in Table 15 and Table 16 reveals the following:

(i) The analysis of the maximum drift ratio values of structures built on type-II soil shows that the ratio of the maximum drift ratio of structures under the influence of near-field earthquakes to that under the influence of far-field earthquakes increases 1.8 and 1.94 times, respectively, in 5- and 8-storey structures with type-II soil. Assessing the maximum drift values of structures constructed on type-III soil indicates that the ratio of the maximum drift under the influence of near-field earthquakes to that under the influence of far-field earthquakes increases 1.17 and 1.97 times, respectively, in 5- and 8-storey structures with type-III soil. Thus, in both soil types, the maximum drift of structures is greater under the influence of near-field earthquakes with a progressive direction-taking than that under the influence of far-field earthquakes.

(ii) The maximum displacement values of structures constructed on type-II soil indicates that the ratio of 

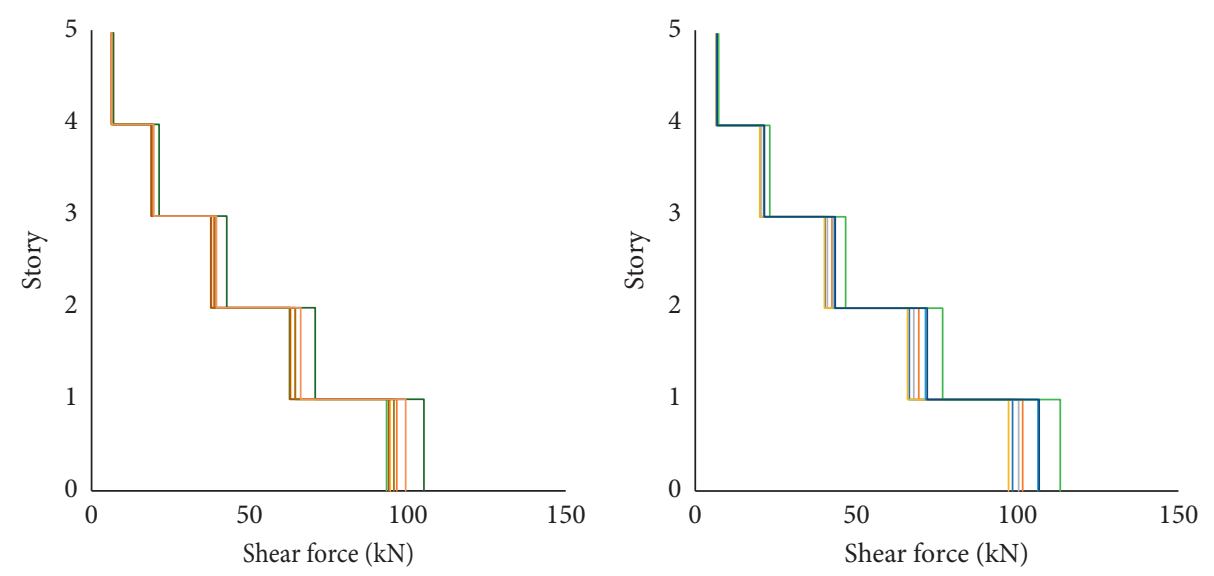

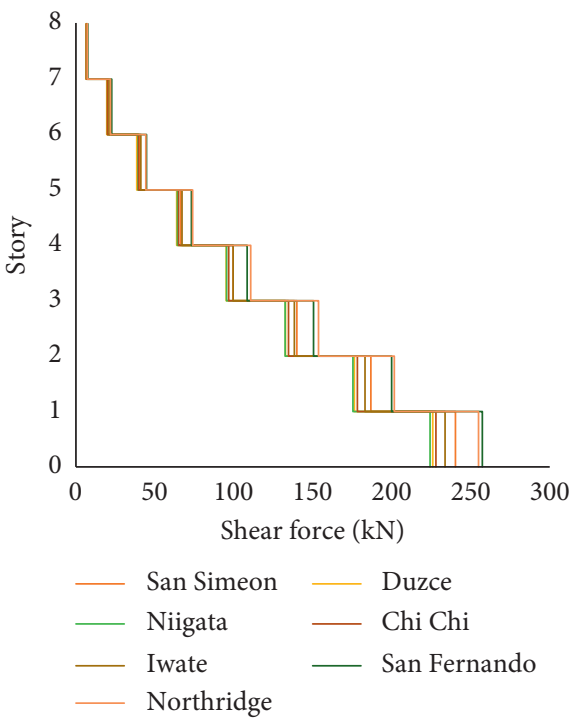

(a)

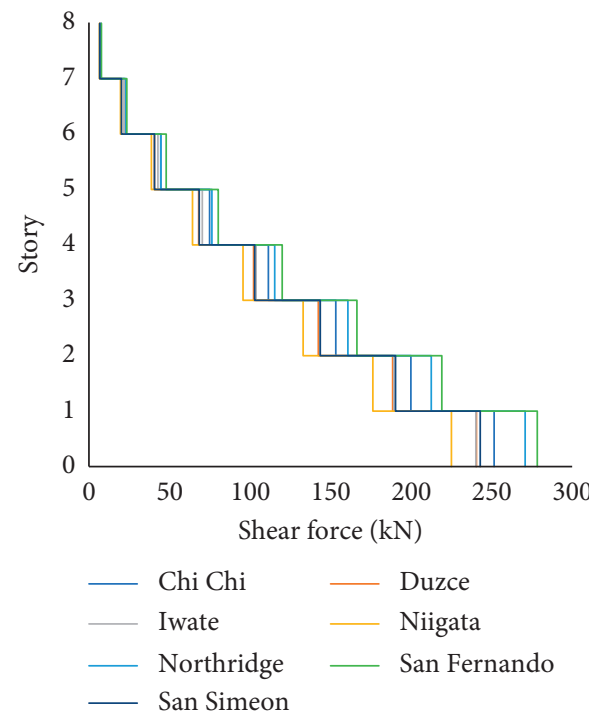

(b)

FIGURE 15: Shear story variations of 5- and 8-story frames under far-field records. (a) Soil type II and (b) soil type III.

TABLE 12: Average of shear story under near-field records.

\begin{tabular}{lccc}
\hline Story & Soil II $(\mathrm{kN})$ & Soil III $(\mathrm{kN})$ & Ratio $(\mathrm{II} / \mathrm{III})$ \\
\hline 5 & 96.93 & 102.63 & 0.94 \\
8 & 237.77 & 249.91 & 0.95 \\
\hline
\end{tabular}

the maximum structure displacement under the influence of near-field earthquakes to that under the influence of far-field earthquakes is 4 and 3.75 , respectively, in 5 - and 8 -storey structures with typeII soil. The maximum displacement values of structures constructed on type-III soil indicate that the ratio of the maximum displacement under the influence of near-field earthquakes to that under the influence of far-field earthquakes increases 2.77 and 3.78 times, respectively, in 5- and 8-storey structures with type-III soil. The maximum axial force on the columns of structures constructed on type-II soil indicates that the ratio of the maximum axial force on columns under the influence of nearfield earthquakes to that under the influence of far-field earthquakes increases 1.18 and 1.28 times, respectively, in 5- and 8-storey structures with typeII soil. The examination of the maximum axial force on the columns of structures constructed on type-III soil indicates that the ratio of the maximum axial force under the influence of near-field earthquakes to that under the influence of far-field earthquakes increases 1.16 and 1.24, respectively, in 5- and 8storey structures with type-III soil.

(iii) The maximum moment values in the columns of structures constructed on type-II soil indicate that the ratio of the maximum moment in columns under the influence of near-field earthquakes to that under the influence of far-field earthquakes increases 1.38 and 1.47 times, respectively, in 5- and 8storey structures with type-II soil. The examination of the maximum moment of the columns of both structures constructed on type-III soil indicates that the ratio of the maximum moment under the influence of near-field earthquakes to that under the influence of far-field earthquakes is 1.58 and 1.83 , 


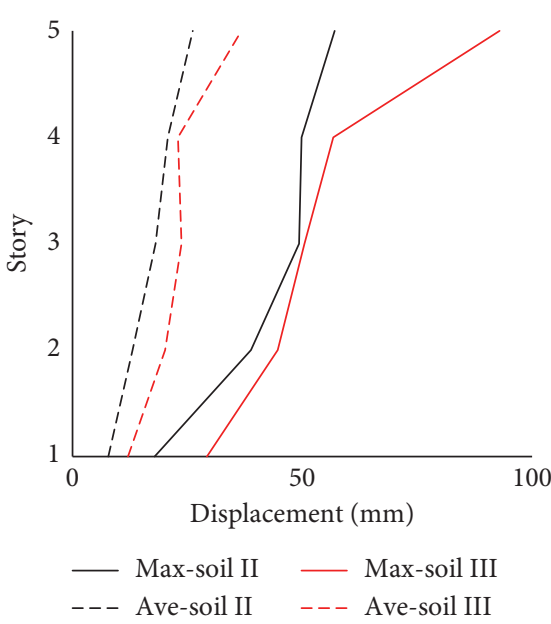

(a)

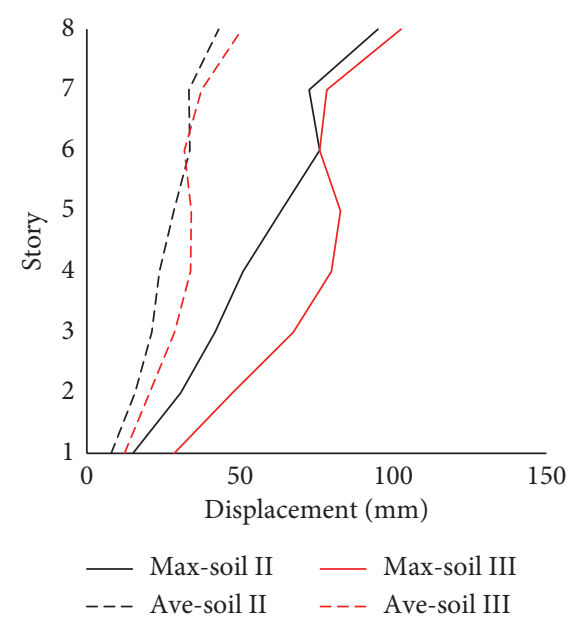

(b)

FIgURE 16: Maximum floor displacement variations of (a) 5-story and (b) 8-story frames under far-field records.

TABLE 13: Average of maximum floor displacement under far-field records.

\begin{tabular}{lccc}
\hline Story & Soil II $(\mathrm{mm})$ & Soil III $(\mathrm{mm})$ & Ratio (II/III) \\
\hline 5 & 34.13 & 47.76 & 0.71 \\
8 & 43.21 & 51.85 & 0.83 \\
\hline
\end{tabular}

TABle 14: Average of maximum column force under far-field records.

\begin{tabular}{ccccccc}
\hline \multirow{5}{*}{ Story } & \multicolumn{3}{c}{ Column axial force $(\mathrm{kN})$} & \multicolumn{3}{c}{ Column moment force $(\mathrm{kN} \cdot \mathrm{m})$} \\
& Soil II & Soil III & $\begin{array}{c}\text { Ratio } \\
(\mathrm{II} / \mathrm{III})\end{array}$ & Soil II & Soil III & $\begin{array}{c}\text { Ratio } \\
(\mathrm{II} / \mathrm{III})\end{array}$ \\
\hline 5 & 5.29 & 6.67 & 0.79 & 2.83 & 4.11 & 0.68 \\
8 & 9.90 & 10.97 & 0.90 & 4.35 & 4.52 & 0.96 \\
\hline
\end{tabular}

respectively, in 5- and 8-storey structures with typeIII soil.

(iv) The comparison of the base shear force in a 5-storey structure with type-II soil under the influence of near-field and far-field earthquakes indicates that the base shear force of this structure is 1.17 times higher under the influence of a near-field earthquake than under the influence of a far-field earthquake. Similarly, the ratio in an 8-storey structure with type-II soil is equal to 1.16. A similar trend reveals that these ratios are 1.12 and 1.19 in 5and 8-storey structures on type-II soil.

\section{Conclusions}

Design regulations of resistant structures against earthquake in Iran classify the type of soil into 4 groups, types I, II, III, and IV. In this paper, the difference of seismic behavior of steel special moment frames constructed on types II and III soils subjected to far- and near-field earthquakes with forward directivity has been studied. In order to acquire comprehensive results, the effects of soil-structure interaction and panel zone in modeling of the frames have been considered. To model soil structure, the interaction direct method was utilized. According to classification of HAZUS-MH MR5 [49] regulation, 5- and 8-story buildings are considered as medium- and high-rise buildings. The following results were obtained by undertaking nonlinear time-history analysis for modeling the aforementioned structures:

(i) The results obtained from the structures subjected to near-field earthquakes with forward directivity show that the maximum drift in 5-story buildings on type-II soil in relation to type-III soil has increased around $3 \%$. This parameter in 8 -story buildings on type-II soil has augmented about $23 \%$ in relation to type-III soil. On the other hand, in analyzing structures subjected to far-field earthquakes, a different trend can be seen in the sense that the maximum drift in 5-story buildings on type-II soil was decreased approximately $30 \%$ in comparison with the obtained values for type-III soil. But, similar to near-field earthquakes, in 8story structures on type-II in proportion to type-III soil, this value declined about $20 \%$.

(ii) Applying 7 near-field earthquake records with forward directivity showed that the maximum difference between shear force value in the 5-story structures on type-II and 5-story structures on typeIII soil is insignificant, around $2 \%$. This comparison revealed that the maximum shear force created in 8 story buildings on type-III soil is $11 \%$ greater than the value obtained for type-III soil. Moreover, applying 7 far-field earthquakes records, it can be said that the maximum base shear force in a 5-story building on type-III soil in relation to the 5-story structure on type-II soil had increased to about 7\%. This comparison for the 8 -story building was about $8 \%$.

(iii) Studying the obtained results demonstrate that in both far- and near-field earthquakes, the maximum base shear force has been obtained for type-III soil. 
TABLE 15: A comparison of the maximum drift ratio, displacement, base shear, and moment of columns due to near-field earthquakes with progressive direction-taking and in far-field earthquakes.

\begin{tabular}{|c|c|c|c|c|c|c|}
\hline \multirow{3}{*}{$\begin{array}{l}\text { Type of building } \\
\text { Type of soil } \\
\text { Type of fault }\end{array}$} & \multicolumn{6}{|c|}{ 5-story building } \\
\hline & \multicolumn{3}{|c|}{ Soil type II } & \multicolumn{3}{|c|}{ Soil type III } \\
\hline & NF & FF & Ratio (NF/FF) & NF & FF & Ratio (NF/FF) \\
\hline & 0.025 & 0.0141 & & 0.0240 & 0.02048 & \\
\hline Drift ratio & San Fernando & San Fernando & 1.80 & $\begin{array}{l}\text { Loma Prieta } \\
\text { Los Gatos }\end{array}$ & San Fernando & 1.17 \\
\hline & 303.29 & 74.15 & & 334.66 & 120.807 & \\
\hline Displacement (mm) & $\begin{array}{l}\text { Loma Prieta } \\
\text { Gilroy Array }\end{array}$ & San Fernando & 4.00 & $\begin{array}{l}\text { Loma Prieta } \\
\text { Los Gatos }\end{array}$ & San Fernando & 2.77 \\
\hline Axial column force $(\mathrm{kN})$ & $\begin{array}{c}11.12 \\
\text { Landers }\end{array}$ & $\begin{array}{l}9.40 \\
\text { San Fernando }\end{array}$ & 1.18 & $\begin{array}{l}12.63 \\
\text { San Fernando }\end{array}$ & $\begin{array}{c}10.90 \\
\text { San Fernando }\end{array}$ & 1.15 \\
\hline Moment column $(\mathrm{kN} \cdot \mathrm{m})$ & $\begin{array}{l}9.29 \\
\text { Loma Prieta } \\
\text { Gilroy Array }\end{array}$ & $\begin{array}{c}6.73 \\
\text { San Fernando }\end{array}$ & 1.38 & $\begin{array}{c}11.63 \\
\text { Loma Prieta } \\
\text { Los Gatos }\end{array}$ & $\begin{array}{c}7.34 \\
\text { San Fernando }\end{array}$ & 1.58 \\
\hline Shear force $(\mathrm{kN})$ & $\begin{array}{c}123.38 \\
\text { Loma Prieta } \\
\text { Gilroy Array }\end{array}$ & $\begin{array}{c}105.15 \\
\text { San Fernando }\end{array}$ & 1.173 & $\begin{array}{l}125.49 \\
\text { Loma Prieta } \\
\text { Los Gatos }\end{array}$ & $\begin{array}{c}112.40 \\
\text { San Fernando }\end{array}$ & 1.116 \\
\hline
\end{tabular}

TABLE 16: A comparison of the maximum drift ratio, displacement, base shear, and moment of columns due to near-field earthquakes with progressive direction-taking and in far-field earthquakes.

\begin{tabular}{|c|c|c|c|c|c|c|}
\hline \multirow{3}{*}{$\begin{array}{l}\text { Type of building } \\
\text { Type of soil } \\
\text { Type of fault }\end{array}$} & \multicolumn{6}{|c|}{ 8-story building } \\
\hline & \multicolumn{3}{|c|}{ Soil type II } & \multicolumn{3}{|c|}{ Soil type III } \\
\hline & NF & $\mathrm{FF}$ & Ratio (NF/FF) & NF & $\mathrm{FF}$ & Ratio (NF/FF) \\
\hline \multirow[b]{2}{*}{ Drift ratio } & 0.0242 & 0.0125 & \multirow[b]{2}{*}{1.94} & 0.0196 & 0.01 & \multirow[b]{2}{*}{1.97} \\
\hline & San Fernando & San Fernando & & $\begin{array}{l}\text { Loma Prieta } \\
\text { Los Gatos }\end{array}$ & San Fernando & \\
\hline \multirow[b]{2}{*}{ Displacement (mm) } & 356.63 & 95.03 & \multirow[b]{2}{*}{3.75} & 387.69 & 102.568 & \multirow[b]{2}{*}{3.78} \\
\hline & San Fernando & San Fernando & & $\begin{array}{l}\text { Loma Prieta } \\
\text { Los Gatos }\end{array}$ & San Fernando & \\
\hline \multirow[t]{2}{*}{ Axial column force $(\mathrm{kN})$} & $\begin{array}{c}21.56 \\
\text { Landers }\end{array}$ & $\begin{array}{c}16.80 \\
\text { San Fernando }\end{array}$ & \multirow[t]{2}{*}{1.28} & $\begin{array}{c}22.84 \\
\text { San Fernando }\end{array}$ & $\begin{array}{c}18.35 \\
\text { San Fernando }\end{array}$ & \multirow[t]{2}{*}{1.24} \\
\hline & 11.72 & 7.94 & & 14.90 & 8.13 & \\
\hline \multirow[t]{2}{*}{ Moment column $(\mathrm{kN} \cdot \mathrm{m})$} & $\begin{array}{l}\text { Loma Prieta } \\
\text { Gilroy Array }\end{array}$ & San Fernando & \multirow[t]{2}{*}{1.47} & $\begin{array}{l}\text { Loma Prieta } \\
\text { Los Gatos }\end{array}$ & San Fernando & \multirow[t]{2}{*}{1.83} \\
\hline & 297.81 & 257.34 & & 332.48 & 278.34 & \\
\hline Shear force $(\mathrm{kN})$ & San Fernando & San Fernando & 1.157 & $\begin{array}{l}\text { Loma Prieta } \\
\text { Los Gatos }\end{array}$ & San Fernando & 1.195 \\
\hline
\end{tabular}

(iv) Investigating the average maximum displacement of stories subjected to 7 far- and near-field earthquake records makes apparent that the average maximum displacement of stories in 5-story structures on type-II soil in relation to type-III soil has increased to $13 \%$. This comparison for 8 -story buildings shows that this parameter has decreased to around $12 \%$ for type-II soil compared with typeIII soil. Furthermore, the results obtained from applying 7 far-field earthquake records to the 4 structures showed that the maximum displacement of the stories in 5-story building on type-II in relation to type-III soil has increased to around $29 \%$, whereas for 8-story building, this parameter has decreased to about $7 \%$.

(v) Evaluating the average maximum axial force caused in columns of the four structure subjected to near-field earthquakes shows that the average maximum axial forces in columns of 5- and 8story buildings on type-II soil are $14 \%$ and $20 \%$ lower than the average maximum axial forces in 5and 8-story buildings on type-III soil, respectively. Following that, the average maximum axial forces subjected to far-field earthquakes in 5- and 8-story buildings on type-II soil are $21 \%$ and $10 \%$ lower than the values obtained on type-III soil. Overall, the average maximum axial forces produced on type-III soil subjected to far- and near-field earthquakes are greater than the corresponding values on type-II soil.

(vi) By assessing the maximum moment created in columns in each of the 4 structures subjected to near-field earthquakes, it can be said that the maximum moment of the columns in 5- and 8story structures on type-II soil are $17 \%$ and $24 \%$ lower than the maximum moment in 5- and 8-story 
structure on type-III soil, respectively. Following that, the average maximum moment in 5- and 8story structures in type-II soil are $32 \%$ and $4 \%$ lower than the average maximum moment in 5and 8-story buildings on type-III soil, respectively. On the whole, the average maximum produced moment in structures on type-III soil subjected to far- and near-field earthquakes are greater than the corresponding values in structures on type-II soil.

(vii) In general, the drift, displacement, base shear force, moment, and axial force of columns in both types of soil are greater under the influence of near-field earthquakes compared with far-field earthquakes.

\section{Data Availability}

No data were used to support this study.

\section{Conflicts of Interest}

The authors declare that they have no conflicts of interest regarding the publication of this paper.

\section{Acknowledgments}

This research was supported by a grant (18TBIP-C14431501) from Technology Business Innovation Program (TBIP) funded by the Ministry of Land, Infrastructure and Transport of Korean government.

\section{References}

[1] G. Minasidis, G. D. Hatzigeorgiou, and D. E. Beskos, "SSI in steel frames subjected to near-fault earthquakes," Soil Dynamics and Earthquake Engineering, vol. 66, pp. 56-68, 2014.

[2] P. Fogazzi and F. Perotti, "The dynamic response of seabed anchored floating tunnels under seismic excitation," Earthquake Engineering and Structural Dynamics, vol. 29, no. 3, pp. 273-295, 2000.

[3] D. Forcellini, "Seismic assessment of a benchmark based isolated ordinary building with soil structure interaction," Bulletin of Earthquake Engineering, vol. 16, no. 5, pp. 20212042, 2018.

[4] H. Jahankhah and P. F. Farashahi, "The effect of foundation embedment on net horizontal foundation input motion: the case of strip foundation with incomplete contact to nearby medium," Soil Dynamics and Earthquake Engineering, vol. 96, pp. 35-48, 2017.

[5] E. Sáez, F. Lopez-Caballero, and A. Modaressi-FarahmandRazavi, "Inelastic dynamic soil-structure interaction effects on moment-resisting frame buildings," Engineering Structures, vol. 51, pp. 166-177, 2013.

[6] C. Stamatopoulos, P. Petridis, M. Bassanou, S. Allkja, N. Loukatos, and A. Small, "Improvement of dynamic soil properties induced by preloading verified by a field test," Engineering Geology, vol. 163, pp. 101-112, 2013.

[7] S. Carbonari, M. Morici, F. Dezi, and G. Leoni, "Analytical evaluation of impedances and kinematic response of inclined piles,” Engineering Structures, vol. 117, pp. 384-396, 2016.

[8] F. Dezi, S. Carbonari, and M. Morici, "A numerical model for the dynamic analysis of inclined pile groups," Earthquake
Engineering and Structural Dynamics, vol. 45, no. 1, pp. 45-68, 2016.

[9] P. Rajeev and S. Tesfamariam, "Seismic fragilities of nonductile reinforced concrete frames with consideration of soil structure interaction," Soil Dynamics and Earthquake Engineering, vol. 40, pp. 78-86, 2012.

[10] M. J. Givens, G. Mylonakis, and J. P. Stewart, "Modular analytical solutions for foundation damping in soil-structure interaction applications," Earthquake Spectra, vol. 32, no. 3, pp. 1749-1768, 2016.

[11] S. Montoya-Noguera and F. Lopez-Caballero, "Effect of coupling excess pore pressure and soil deformation on nonlinear SSI in liquefiable soil deposits," Bulletin of Earthquake Engineering, vol. 16, no. 2, pp. 681-705, 2018.

[12] A. Anvarsamarin, F. R. Rofooei, and M. Nekooei, "Soilstructure interaction effect on fragility curve of 3D models of concrete moment-resisting buildings," Shock and Vibration, vol. 2018, pp. 1-13, 2018.

[13] X. Wang, K. Liu, H. Liu, and Y. He, "Damping identification with acceleration measurements based on sensitivity enhancement method," Shock and Vibration, vol. 2018, pp. 1-16, 2018.

[14] X. Zhao, S. Wang, D. Du, and W. Liu, "Optimal design of viscoelastic dampers in frame structures considering soilstructure interaction effect," Shock and Vibration, vol. 2017, pp. 1-16, 2017.

[15] G. Mylonakis and G. Gazetas, "Seismic soil-structure interaction: beneficial or detrimental?," Journal of Earthquake Engineering, vol. 4, no. 3, pp. 277-301, 2000.

[16] J. Qian and D. E. Beskos, "Dynamic interaction between 3-D rigid surface foundations and comparison with the ATC-3 provisions," Earthquake Engineering and Structural Dynamics, vol. 24, no. 3, pp. 419-437, 1995.

[17] Z. Tang, H. Ma, J. Guo, and Z. Li, "Effect of soil-structure interaction on seismic performance of long-span bridge tested by dynamic substructuring method," Shock and Vibration, vol. 2017, pp. 1-12, 2017.

[18] FEMA P-750, NEHRP Recommended Seismic Provisions for New Buildings and Other Structures, Federal Emergency Management Agency, Washington, D.C., USA, 2009.

[19] K. K. F. Wong and R. Yang, "Comparing response of SDF systems to near-fault and far-fault earthquake motions in the context of spectral regions," Earthquake Engineering and Structural Dynamics, vol. 30, no. 12, pp. 1769-1789, 2001.

[20] S. Akkar, U. Yazgan, and P. Gülkan, "Drift estimates in frame buildings subjected to near-fault ground motions," Journal of Structural Engineering, vol. 131, no. 7, pp. 1014-1024, 2005.

[21] V. V. Cao and H. R. Ronagh, "Correlation between seismic parameters of far-fault motions and damage indices of lowrise reinforced concrete frames," Soil Dynamics and Earthquake Engineering, vol. 66, pp. 102-112, 2014.

[22] S. Zhang and G. Wang, "Effects of near-fault and far-fault ground motions on nonlinear dynamic response and seismic damage of concrete gravity dams," Soil Dynamics and Earthquake Engineering, vol. 53, pp. 217-229, 2013.

[23] A. Farzampour and A. Kamali Asl, "On seismic hazard analysis of the two vulnerable regions in Iran: deterministic and probabilistic approaches," in Proceedings of 2014 NZSEE Conference, New Zealand, March 2014.

[24] A. Farzampour and A. Kamali-Asl, "Seismic hazard assessment for two cities in Eastern Iran," Earthquake and Structures, vol. 8, no. 3, pp. 681-697, 2015.

[25] S. Adanur, A. C. Altunişik, A. Bayraktar, and M. Akköse, "Comparison of near-fault and far-fault ground motion 
effects on geometrically nonlinear earthquake behavior of suspension bridges," Natural Hazards, vol. 64, no. 1, pp. 593-614, 2012.

[26] P. G. Somerville, "Magnitude scaling of the near fault rupture directivity pulse," Physics of the Earth and Planetary Interiors, vol. 137, no. 1-4, pp. 201-212, 2003.

[27] P. Raychowdhury and P. Singh, "Effect of nonlinear soilstructure interaction on seismic response of low-rise SMRF buildings," Earthquake Engineering and Engineering Vibration, vol. 11, no. 4, pp. 541-551, 2012.

[28] M. Ghandil and F. Behnamfar, "The near-field method for dynamic analysis of structures on soft soils including inelastic soil-structure interaction," Soil Dynamics and Earthquake Engineering, vol. 75, pp. 1-17, 2015.

[29] M. Gerami and D. Abdollahzadeh, "Vulnerability of steel moment-resisting frames under effects of forward directivity," Structural Design of Tall and Special Buildings, vol. 24, no. 2, pp. 97-122, 2015.

[30] V. Dimakopoulou, M. Fragiadakis, and C. Spyrakos, "Influence of modeling parameters on the response of degrading systems to near-field ground motions," Engineering Structures, vol. 53, pp. 10-24, 2013.

[31] C. Champion and A. Liel, "The effect of near-fault directivity on building seismic collapse risk," Earthquake Engineering and Structural Dynamics, vol. 41, no. 10, pp. 1391-1409, 2012.

[32] N. Rahgozar, A. S. Moghadam, and A. Aziminejad, "Response of self-centering braced frame to near-field pulse-like ground motions," Structural Engineering and Mechanics, vol. 62, no. 4, pp. 497-506, 2017.

[33] BHRC, Iranian Code of Practice for Seismic Resistant Design of Buildings: Standard 2800, BHRC, Tehran, Iran, 4th edition, 2014.

[34] A. Gupta and H. Krawinkler, "Seismic demands for the performance evaluation of steel moment resisting frame structures," Report 132, Stanford University, Stanford, CA, USA, 1999.

[35] OpenSees: Open System for Earthquake Engineering, http:// opensees.berkeley.edu/wiki/index.php/Main_Page.

[36] L. F. Ibarra, R. A. Medina, and H. Krawinkler, "Hysteretic models that incorporate strength and stiffness deterioration," Earthquake Engineering and Structural Dynamics, vol. 34, no. 12, pp. 1489-1511, 2005.

[37] H. R. Tabatabaiefar and A. Massumi, "A simplified method to determine seismic responses of reinforced concrete moment resisting building frames under influence of soil-structure interaction," Soil Dynamics and Earthquake Engineering, vol. 30, no. 11, pp. 1259-1267, 2010.

[38] K. D. Pitilakis, S. T. Karapetrou, and S. D. Fotopoulou, "Consideration of aging and SSI effects on seismic vulnerability assessment of RC buildings," Bulletin of Earthquake Engineering, vol. 12, no. 4, pp. 1755-1776, 2014.

[39] Y. Zhang, J. P. Conte, Z. Yang, A. Elgamal, J. Bielak, and G. Acero, "Two-dimensional nonlinear earthquake response analysis of a bridge-foundation-ground system," Earthquake Spectra, vol. 24, no. 2, pp. 343-386, 2008.

[40] E. Esmaeilzadeh Seylabi, C. Jeong, and E. Taciroglu, "On numerical computation of impedance functions for rigid soilstructure interfaces embedded in heterogeneous half-spaces," Computers and Geotechnics, vol. 72, pp. 15-27, 2016.

[41] S. Ghosh and E. L. Wilson, "Dynamic stress analysis of axisymmetric structures under arbitrary loading," Report EERC 69-10, University of California, Berkeley, CA, USA, 1969.

[42] S. J. Feng, X. L. Zhang, Q. T. Zheng, and L. Wang, "Simulation and mitigation analysis of ground vibrations induced by high-speed train with three dimensional FEM," Soil Dynamics and Earthquake Engineering, vol. 94, pp. 204-214, 2017.

[43] D. G. Lignos and H. Krawinkler, "Deterioration modeling of steel components in support of collapse prediction of steel moment frames under earthquake loading," Journal of Structural Engineering, vol. 137, no. 11, pp. 1291-1302, 2011.

[44] J. P. Singh, "Earthquake ground motions: implications for designing structures and reconciling structural damage," Earthquake Spectra, vol. 1, no. 2, pp. 239-270, 1985.

[45] B. Alavi and H. Krawinkler, "Behavior of moment-resisting frame structures subjected to near-fault ground motions," Earthquake Engineering and Structural Dynamics, vol. 33, no. 6, pp. 687-706, 2004.

[46] E. Kalkan and S. K. Kunnath, "Effects of fling step and forward directivity on seismic response of buildings," Earthquake Spectra, vol. 22, no. 2, pp. 367-390, 2006.

[47] M. Harati, A. H. Sabet, and A. H. Modaraei, "An investigation on the effect of the near-fault earthquakes on the seismic behavior of RC Moment Resisting Frames (MRFs) designed based on Iranian seismic code (standard 2800)," Journal of Engineering and Applied Sciences, vol. 11, no. 2, pp. 274-283, 2016.

[48] M. Khatibinia, Reliability-based design optimization of reinforced concrete structures including soil-structure interaction, Ph.D. thesis, Shahid Bahonar University of Kerman, Iran, 2013.

[49] HAZUS-MH MR5, Multi-Hazard Loss Estimation Methodology: Earthquake Model, Federal Emergency Management Agency, Washington D.C., USA, 2011. 


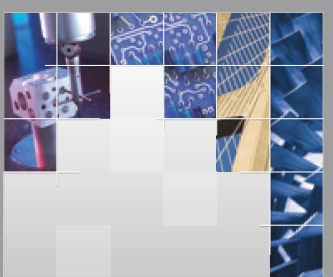

\section{Enfincering}
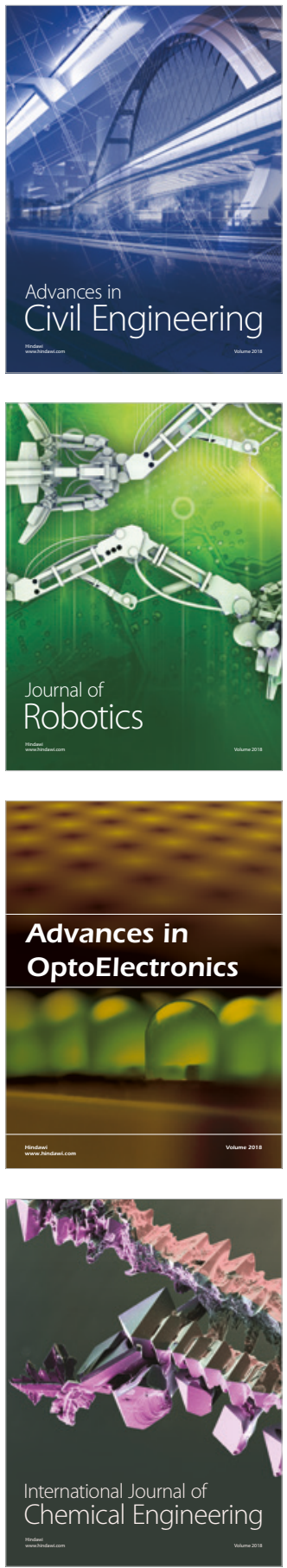

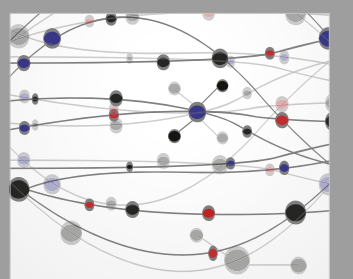

\section{Rotating \\ Machinery}

The Scientific World Journal

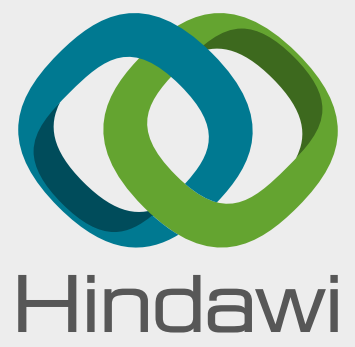

Submit your manuscripts at

www.hindawi.com
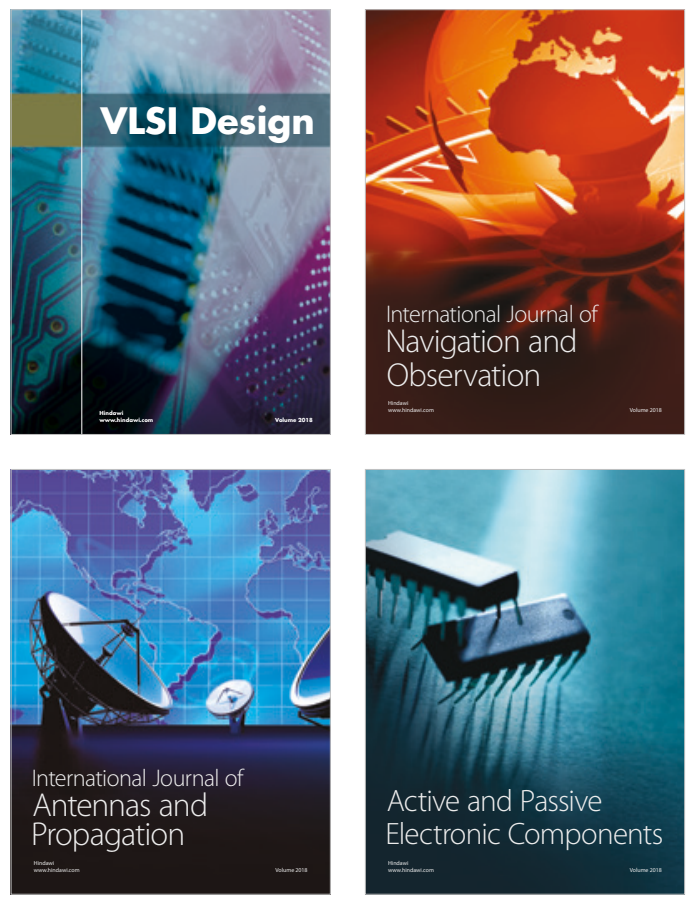
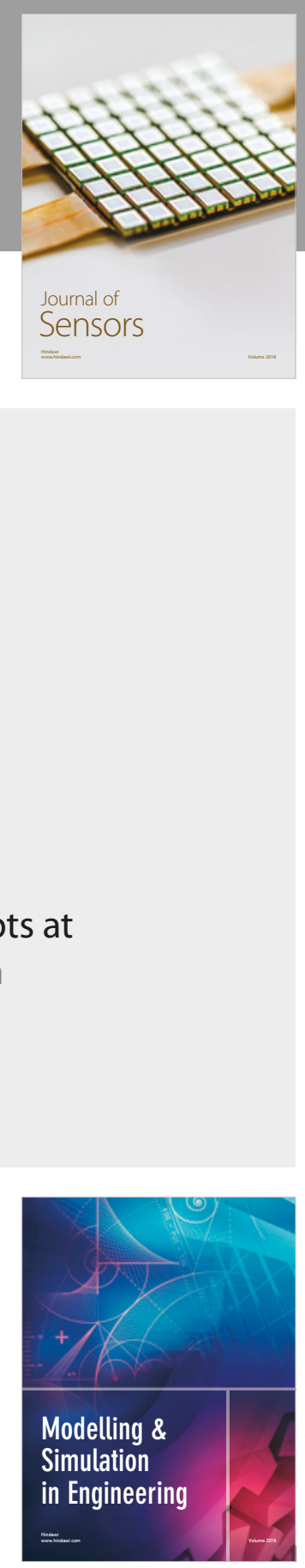

\section{Advances \\ Multimedia}
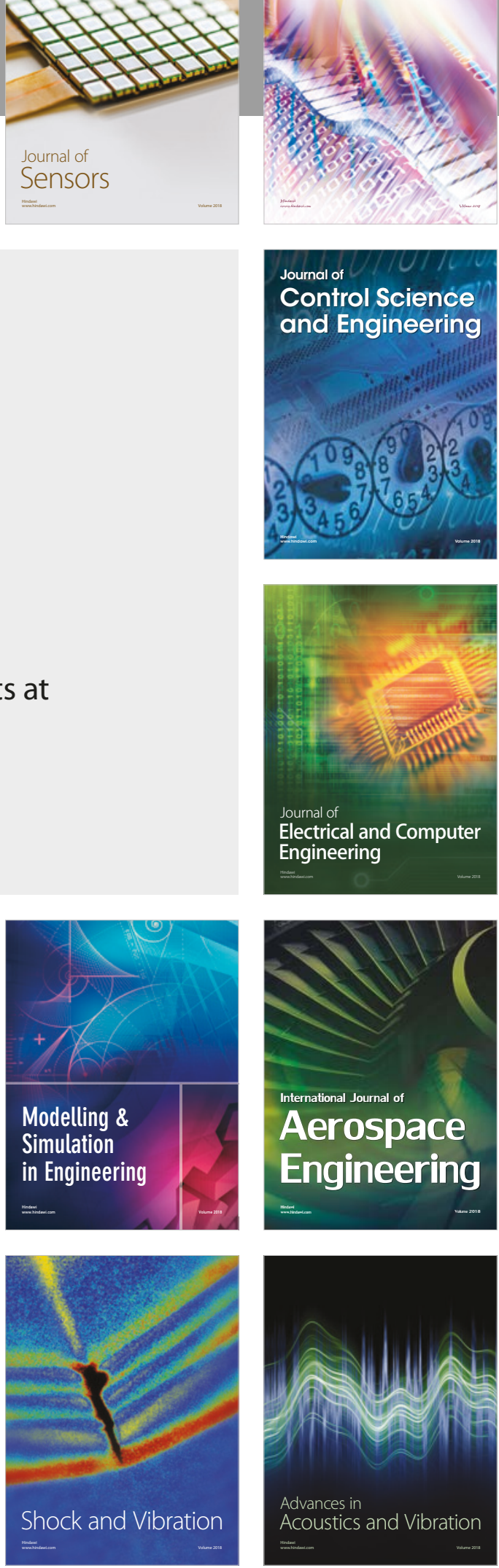